\title{
Jak se rodí gender v diagnostickém ústavu
}

\author{
Jana Benešová
}

\begin{abstract}
Abstrakt: Článek je extraktem výzkumných zjištění, jež se týkají (re)konstrukcí genderových identit dětí umístěných v soudobém dětském diagnostickém ústavu v ČR, který $v$ textu z etických důvodů vystupuje pod fiktivním názvem DDÚ Archa. Autorka v něm shrnuje průběžné výsledky disertačního projektu, který realizuje na FHS UK v Praze. Cílem je zachytit procesy, jimž česká odborná komunita dosud nevěnuje náležitou pozornost a které se $v$ praxi mohou stávat nereflektovanými disciplinačními nástroji v rukou pracovníků a pracovnic širokého spektra odborností na pomezí sociální a speciální pedagogiky.
\end{abstract}

Klíčová slova: dětský diagnostický ústav, gender, moc, hustý popis

\section{1 ÚVOD}

Koncept genderu, konstruovaného aspektu naší identity, stavěl v počátečních feministických úvahách na kontrapozici ke konceptu pohlaví, vrozenému atributu naší identity. Užití pojmu "gender" $v$ souvislosti s rozením, jako je tomu v titulku této studie, by tak mohlo zdánlivě představovat oxymorón. Není mým záměrem zde představovat argumenty z pozdějších fází feministických diskuzí, kdy byla dichotomie pohlaví a genderu zpochybněna a poukázáno bylo na kulturně konstruovanou povahu samotného pohlaví (Butler, 1990). Případné podežrení z protimluvu musím odmítnout z jiného zásadního důvodu. Gender se totiž v prostředí diagnostického ústavu skutečně svým způsobem rodí - mocenské vlivy v tomto prostoru dávají vzniknout specifické genderové identitě. $\mathrm{Na}$ rozvoj ideálních genderových charakteristik a rolí je zde kladen zvláštní důraz. Až takový, že by se kýžená resocializace jedince v ústavu dala nazvat resocializací genderovou (detailně Bobková, 2009).

Možné důvody zesíleného tlaku na „genderovou konformitu“ v instituci usilující o nápravu vztahů či chování lze hledat v dosavadních sociologických poznatcích (Goffman, 1976), ale i u nesociologů Foucault by zřejmě argumentoval explozí diskurzů v zájmu sumarizace vědění o "napravovaném" jedinci. (A tak bychom mohli od „zrození kliniky“ /Foucault, 2010/ analogicky odvodit „zrození diagnostického ústavu“). Tato etnografická studie se pokouší nabízet interpretace účinků moci $v$ instituci, avšak oproti Foucaultovým analýzám s důrazem na jejich genderový rozměr.

Přestože diagnostické ústavy jsou v ČR označovány za zařízení speciálně pedagogická, tento článek se snaží nepřímo poukázat na relevanci tématu pro obor sociální pedagogiky. Stejně jako prostředí DDú je totiž sociální pedagogika do značné míry interdisciplinární. V diagnostickém ústavu se sbíhá řada různých odborností, na něž je delegována pravomoc terapeutického působení - vychovatelství, psychologie, medicína, sociální práce aj. Diskurzivní splývání diagnostických ústavů s "represí" je neblahou skutečností, kterou by snad pomohl eliminovat zvýšený zájem odborníků a odbornic z oblasti sociální pedagogiky. Je-li totiž něco společné všem umístěným dětem, pak to nejsou výchovné problémy, nýbrž sociální znevýhodnění (dostavující se ovšem i v důsledku absolvovaného pobytu v DDÚ). Následující text necht' je chápán jako kritika diskurzů pomáhajících profesí v českém systému ústavní a ochranné výchovy, nikoliv jako kritika konkrétní instituce či jejích zaměstnanců/kyň.

\footnotetext{
${ }^{1}$ Není autorčiným záměrem vytvářet falešnou dichotomii mezi prostředím „umělým“ (DDÚ) a prostředím „přirozeným“ (původním každého konkrétního dítěte). Jak ukázala již pilotní studie autorky, součástí působení DDÚ jsou disciplinační praktiky s př́mým vztahem k genderu, které lze těžko považovat za obvyklé výchovné prostředky používané $v$ rodinách či komunitách.
} 
Těm patří velké poděkování za otevřenost a ochotu zapojit se do terénního výzkumu autorky v DDÚ Archa. Poděkování náleží rovněž řediteli/ce DDÚ Archa za povolení k uskutečnění výzkumné studie.

\section{VÝZKUM DDÚ ARCHA}

Česká odborná komunita vykazuje dluh v oblasti studia institucí s využitím genderu jako analytické kategorie. Výjimku na tomto poli představuje publikovaná rigorózní práce Kateřiny Nedbálkové Sociální (re)produkce genderu a sexuality v ženské věznici (2006). Navzdory laickému pojetí funguje vězení v diskurzu nápravném, zatímco soudobá zařízení pro výkon ústavní a ochranné výchovy $v$ diskurzu (speciálně-)pedagogickém, proto se autorka paralelám cíleně vyhýbá. Genderové ticho v oblasti českého výzkumu institucí (vyjma toho se vztahem k trhu práce, např. Kř́žková, Pavlica, 2004) je jednak jedním z impulzů pro studium DDÚ Archa, ale také důvodem, proč se autorka při interpretacích zř́dka vztahuje $k$ české literatuře. Za inspirativní a podnětné Ize nicméně považovat např́iklad články Radky Janebové, které reflektují vztahy gender/moc v kontextu pomáhajících profesí (níže v textu).

Strategie výzkumu DDÚ Archa je založena na designu př́ipadové studie. Tento metodologický přistup zahrnuje etnografii (terénní výzkum) vybraného diagnostického ústavu. Klíčový metodologický koncept pro zacházení s empirickým materiálem a jeho interpretaci představuje tzv. „zhuštěný popis“ (thick descriptions, Geertz, 2000: 17). Výzkum pomocí prípadové studie se soustředí na detailní popis a rozbor jednoho či několika málo př́padů, přičemž se předpokládá, že tento případ či prípady jsou z hlediska studia daného jevu typické (Hendl, 2005). Epistemologický a metodologický rámec výzkumu je výrazně ovlivněn genderovou perspektivou.

\subsection{Cíl výzkumu}

Cílem výzkumu je prostřednictvím zhuštěného popisu (Geertz, 2000) zachytit prostředky a nástroje, kterými je vinstitucionálním systému českých zařizení pro výkon ústavní a ochranné výchovy (re)produkován genderový raád, určován obsah chlapecké a dívčí role a kterými je ustavována určitá forma sexuality jako preferovaná, zatímco jiné jako nepř́pustné (Thorne, 1978). Předpokladem pro takto specificky stanovený cíl je pro autorku již v minulosti zrealizovaná pilotní studie DDÚ Archa (Bobková, 2009).

Diagnostický ústav je nahližen ze dvou různých perspektiv. První zasazuje DDÚ Archa do kontextu vzájemně provázaného systému rezidenčních zařízení pro výkon ústavní a ochranné výchovy a systému sociálně právní ochrany dětí. Druhá si všímá každodenního fungování svébytné jednotky, která je specifická svými provozními pravidly, programem, vnitřními předpisy či převažujícími metodami práce. Oba pohledy jsou funkčně zakomponovány do výkladu, jenž představuje gender $v$ mnoha předmětných souvislostech.

\subsection{Metoda a vztahy $v$ terénu}

Základní výzkumná otázka je stanovena takto: Jak je re/konstruován gender v českém dětském diagnostickém ústavu a jaké mocenské mechanismy se na této re/konstrukci podílí? Dílčí výzkumné otázky hlavní problém dále rozvíjejí: Jakým způsobem se promítají diskurzy tzv. pomáhajících profesí (tj. psychologický, sociálně-právní, pedagogický, medicínský aj.) do konkrétních praktik genderové disciplinace, $k$ nimž dochází v každodenní realitě institucionálního systému, ve kterém se $v$ českém prostředí realizuje ústavní a ochranná výchova? Jaký mají tyto obíhající diskurzy podíl na legitimizaci mocenských praktik a produkci genderu v ústavním prostředí? 
Výzkum vychází z metodologického designu explorativní př́ípadové studie (Yin cit. in Švaříček, Šed'ová, 2007). Používám výzkumnou metodu etnografie (terénního výzkumu) DDÚ Archa konkrétního českého zařízení pro výkon ústavní a ochranné výchovy (též ÚV a OV).

Součástí terénního výzkumu jsou vždy dílčí metody sběru empirických dat. $V$ mém výzkumném prostředí proto proběhlo zúčastněné pozorování (2007-2009, v době pracovního působení autorky na pozici sociální pracovnice v DDÚ Archa), individuální rozhovory se zaměstnanci/kyněmi (od 2010 po současnost), nezúčastněné pozorování školní výuky (2012) a kvalitativní obsahová analýza tištěných materiálů týkajících se fungování DDú Archa. Jak ovšem argumentují Hammersley a Atkinson (1995), etnografie není jen souborem jednotlivých metod sběru materiálu, ale spiše určitým způsobem nazírání, naslouchání a myšlení o sociálních jevech.

Článek Buchbinder a kol. (2006) dokládá, že etnografické studie jsou velmi dobře aplikovatelné do institucionálního prostředí. Etnografickou studii ústavu pro delikventní chlapce provedla autorská dvojice Kivett \& Warren (2002). Studie zdůrazňuje, že jako každá metoda, i etnografie nazírá sociální realitu určitými čočkami - ve foucaultovské terminologii je určitým způsobem pohledu („gaze“, s. 7).

Aby autorka učinila svůj „gaze“ co nejvíce transparentním, věnuje v následující podkapitole prostor specifikům vlastní výzkumné pozice. Vedle skutečnosti, že autorka tohoto článku je coby bývalá zaměstnankyně DDÚ Archa napůl insiderkou a napůl outsiderkou ve zkoumaném prostředí (více Hammersley, Atkinson, 1995), je významnou charakteristikou její pozicionality vzdělání v oboru sociální práce, genderových studií a sociální antropologie. Při interpretaci empirického materiálu je pro ni klíčová genderová perspektiva (srov. Scott, 1986), odrážející postmoderní pojetí genderu $v$ antropologii (Barnard, 2004). Centrální postavení genderu jako analytické kategorie v tomto výzkumu je opřeno o nosný argument: studie s obdobným akcentem z prostředí ústavů náhradní výchovy v českém kontextu dosud vůbec nebyla zrealizována.

S dvojznačnou pozicionalitou autorky úzce souvisí umožnění vstupu do výzkumného prostředí DDÚ Archa. Vyjednávání přístupu nebylo úplně snadné, přičemž klíčovou roli ve prospěch autorky nakonec sehrála skutečnost, že v minulosti sama odborně působila v DDÚ Archa. Z této doby (2007-2009) také pocházejí statistické podklady týkající se důvodů umist'ování dětí do DDÚ (důsledně anonymizované), deníkovou formou psané poznámky autorky z praxe a rovněž některé dílčí závěry z diplomové práce autorky, která se zabývala trestnou činností umístěných dětí z genderové perspektivy.

Poměrně dlouhá autorčina insider zkušenost pozitivně ovlivnila navazování výzkumných vztahů autorky s participanty/kami individuálních rozhovorů - zaměstnanými DDÚ Archa. Výzkumné vztahy tak byly charakterizovány blízkostí, jak ji tematizují některé feministické badatelky, nicméně ne jako vědomě volený př́stup korigující vzdálenostní přistup v etnografii, jež tyto autorky v duchu falešné dichotomie považují za produkt vývoje mužské historie výzkumu (např. Hochschield cit. in Reinharz, 1992). Autorka tak musela častěji vybalancovávat polohu „úplné participantky“, opakovaně $v$ rozhovorech ozřejmovat participantům/kám nutnost pokládat jim zdánlivě banální otázky - takové, které by člověk $s$ tříletým profesním působením v DDÚ z jejich pohledu neměl důvod pokládat, podněcovat k obšírnějším, informačně bohatším odpovědím atd. Hammersley a Atkinson (1995) uvádějí, že ani vědomě zvolená „role“ etnografa/etnografky nemusí být plně pod jeho/její kontrolou, $s$ délkou pobytu $v$ terénu se proměňuje $v$ kontinuu anonymních až osobních vztahů a $v$ jakémkoli čase může být multidimenzionální.

Do výzkumného vzorku Ize zahrnout jednak nezletilé děti, umístěné v letech -2007-2009 v DDÚ Archa, dále zaměstnance a zaměstnankyně ústavu působící v instituci od roku 2007 po současnost, dokumentaci týkající se fungování a provozu zkoumané instituce (aktualizace do r. 2010), zmíněné deníky z praxe a statistiky týkající se důvodů umistování dětí do DDÚ Archa (zpracovány autorkou nejpozději v r. 2009). 
Mechanismy a praktiky konstruování genderových obsahů jsou v souladu s předmětem výzkumu analyzovány primárně ve vztahu k umístěným dětem. Děti stojí $v$ centru zájmu proto, že jsou praktikami genderové disciplinace ovlivněny významně více než dospělí pracovníci zařízení. Tím není řečeno, že dospělí/é zaměstnanci/kyně jsou pouze „exekutory“ mocenských praktik. Naopak: Jsou současně subjekty $\mathrm{i}$ objekty genderové disciplinace, kterou mohou zakoušet například v důsledku působení genderově necitlivého kurikula disciplín, v jejichž rámci pracují (Kuruc a Smitková, 2007). Jak shrnuje Tew (2006), „pracovníci a pracovnice se sami/y mohou cítit jako objekty omezující či utlačovatelské formy organizační moci“ (s. 46). Umístěné děti se však nacházejí a priori v nerovném postavení a jejich vyjednávací prostor je z hlediska dopadu diskurzivních praktik zásadně limitován.

\subsection{Interpretace a výsledky}

Na úplné transkripce osmi individuálních rozhovorů se zaměstnanými DDÚ Archa, tištěné dokumenty vztahující se k fungování DDÚ Archa (vnitřní raád, pravidla hodnocení, výroční zprávy, webové stránky, provozní raády spádových zařízení a odborné publikace, z nichž zaměstnanci/kyně DDÚ Archa vycházejí při upevňování komunitně-terapeutického systému a provádění diagnostiky) a textové záznamy autorky týkající se předmětu výzkumu (autorkou zpracované statistiky týkající se důvodů umístění nezletilých dětí, poznámky z nezúčastněného pozorování školní výuky, deníky z praxe, poznámky z terénu) byla uplatněna kvalitativní obsahová analýza (Reinharz, 1992; Hendl, 2005).

Podklad pro přepisy rozhovorů představovaly audionahrávky pořizované na diktafon se souhlasem participanta/ky stvrzeným podpisem tzv. informovaného souhlasu. Přepisovány byly hromadně v zimě 2013. Poznámky z nezúčastněného pozorování školní výuky, včetně interpretací, autorka zpracovala (a dle předchozí domluvy poskytla řediteli/ce DDÚ Archa) v odstupu několika dní po uskutečněném pozorování. Ostatní poznámky z terénu byly pořizovány průběžně, nikdy však za př́tomnosti participantů/ek z výzkumného prostředí.

Empirická zjištění provázaná s jejich „hustou interpretaci“ jsou na následujících stránkách rozdělena do šesti tematických linií, na nichž se genderové re/konstrukce zřetelně vykreslují. Dohromady tvoří mozaiku typickou pro etnografický výzkum - záznamy z terénního deníku plasticky přibližující žitou realitu umístěných dětí jsou doplňovány o aplikaci teoretických poznatků v zájmu co nejbohatší interpretace shromážděných dat² .

Nejprve je touto formou představeno výzkumné prostředí (setting), následně je prezentován koncept genderu jako organizační princip (Renzetti, Curran, 2005), jenž má klíčový význam již ve fázi vstupu dítěte do DDÚ. Gender „diagnostický“ je genderovou analýzou podmínek a okolností odchodu dítěte z DDÚ, tzv. dislokačního procesu. Historická optika zasazuje genderové obsahy předávané v DDÚ do širšího rámce a naznačuje, jakým prošel $v$ našich podmínkách vývojem. Kapitola představující působení DDÚ Archa na poli pomáhajících profesí, jako vykonavatele sociálně-pracovních intervencí, nese název "Gender pomáhající. Gender „institucionálni“ je sondou do interních mechanismů studovaného DDÚ Archa a představuje konkrétní aspekty dynamiky moc/vědění (Foucault, 1980) na úrovni jedné vybrané instituce náhradní výchovy. "Gender mocenský“ je pak zastřešující analýzou účinků moci na úrovni celého systému - sítě zařízení pro výkon ústavní a ochranné výchovy.

\footnotetext{
${ }^{2}$ Obecnější úroveň interpretací je v tomto textu opatřena standardní velikostí písma (12); poznámky z terénu, jež se samozřejmě rovněž prolínají s dílčími interpretacemi, jsou psány fontem o dva body menším. Přímé citace respondentů/ek jsou uvedeny v téže velikosti, kurzivou, opatřeny uvozovkami. Článek odráží dosavadní průběh výzkumu autorky a zatím nepodává obsahově zcela vyčerpávající obraz zkoumaného terénu. Jeho finální podoba bude obsahem disertační práce, kterou autorka píše na katedře Obecné antropologie FHS UK pod vedením Yasara Abu Ghoshe, PhD.
} 


\title{
3 KDE SE VZAL DIAGNOSTICKÝ ÚSTAV
}

\author{
„Já myslím, že je to nějaký bezpečný prístav pro děti." (zaměstnankyně DDÚ Archa)
}

Historie diagnostického ústavu jako instituce se odvijí od původních označení „ochranovna“ či „polepšovna“ (Monatová, 1998: 71). Ochranovny u nás vznikaly od druhé poloviny 19. století jako sociálně výchovné instituce, kam byly umistovány děti osiř̌lé, opuštěné, ale i „mravně narušené“ (tamtéž). Zčásti se tak svým zaměřením kryly s polepšovnami, sloužícími výhradně pro děti s výchovnými problémy. Ty začaly být v Rakousku-Uhersku budovány od roku 1885. První vznikaly v Opatovicích, Králíkách a Kostomlatech.

Dvě naposledy jmenované instituce mají v dislokačním diskurzu DDÚ Archa speciální význam. Symbolizují totiž dodnes ta nejrepresivnější (v souladu s diskurzem DDú „ta nejrežimovějši“) zařízení, do kterých může být dítě umístěno. A jako hrozba fungují. Moc dislokační rétoriky působí navíc sofistikovaně: Aby se zdůvodnilo nevyhnutelné umístění některých dětí do přísného výchovného zařízení (např. s ohledem na závažnost prohřešků vanamnéze), používá se formulka: „Jsi dobrý/á, vybojoval/a sis Králíky/Kostomlaty."

V dnešní terminologii je diagnostický ústav, vedle výchovných ústavů, dětských domovů a dětských domovů se školou nazýván institucí pro výkon ústavní a ochranné výchovy (zákon č. 109/2002 Sb.) a je spravován resortem MŠMT. Jeho cílovou skupinou jsou jak děti z dřívějších ochranoven, tak z polepšoven.

Jmenované instituce se někdy označují jako zařízení náhradní výchovy. Ideovým základem je předpoklad, že pečující osoby mohou být úředně zbaveny kompetence vychovávat svěřené osoby, výchova je delegována do rukou státu a stát určuje, k jakým hodnotám bude děti vychovávat. Jak uvádí zákon č. 109/2002 Sb., účelem zařízení pro výkon ÚV a OV je zajištovat nezletilému dítěti na základě rozhodnutí soudu "náhradní výchovnou péči v zájmu jeho zdravého vývoje, raádné výchovy a vzdělávání“ (§ 1 odst. 2, zákona č. 109/2002Sb.). Zdravý vývoj, raádná výchova a vzdělání jsou zákonem svěřeny do rukou konkrétních pracovníků a pracovnic, kteří tyto cíle naplňují v souladu s osobními představami. Samotný proces naplňování cílů nepodléhá prakticky žádným kodifikovaným kritériím a normám. Překvapivě dosud nebyla zformulována ani obdoba Standardů kvality platných pro pomáhající zařízení v gesci MPSV (vyhláška č. 505/2006 Sb.).

\subsection{Gender „organizačni“}

Diagnostický ústav přijímá děti na základě soudního rozhodnutí a podle „výsledků komplexního vyšetření, zdravotního stavu dětí a volné kapacity jednotlivých zařízení je umístúuje do dětských domovů, dětských domovů se školou nebo výchovných ústavư“ (§ 5, odst. 1, zákona č. 109/2002 Sb.). Dětský diagnostický ústav přijímá děti zpravidla od tří let do ukončení povinné školní docházky a je koedukovaný. Oproti tomu diagnostické ústavy pro mládež přijímají děti s ukončenou povinnou školní docházkou a jsou genderově segregované.

Nezletilé děti jsou do zařizení náhradní výchovy umístovány z velmi rozmanitých důvodů, které skýtají prostor pro genderovou analýzu.

Šetření autorky ukázalo, že v období 2003-2008 bylo príjato k diagnostickému pobytu celkem 1763 dětí. Záznam o páchané delikventní činnosti v širším pojetí má z celkového počtu studovaných dětí 202 dívek a 408 chlapců, z nichž 42 dívek a 235 chlapců má záznam o spáchané trestné činnosti (respektive činnosti jinak trestné). Průměrná míra delikvence (tj. v širším pojetí) i trestné činnosti (tj. užší pojetí) je v prrípadě chlapců vyšší než u dívek ( $v$ prípadě delikventní činnosti činí rozdíl $11,2 \%$, v prŕpadě trestné činnosti jde o $16,8 \%$ ). 
Alarmující je však skutečnost, že celkově nejčastějším prohřeškem, za který jsou umístovány dívky, je tzv. předčasný sexuální život, kdežto u chlapců nebyl popsán ani jeden takto klasifikovaný př́pad. Naopak v devíti prípadech byla u chlapců zaznamenána trestná činnost se sexuálním podtextem (sexuální zneužití, /pokus o/ znásilnění). U dívek nebylo sexuálně motivované násilí identifikováno ani v jednom př́padě.

Dívky tedy nejsou do zařízení pro výkon ÚV a OV primárně umístovány pro trestnou činnost, zatímco u chlapců je tomu přesně naopak. Nejčastějšími prohřešky dívek jsou statusové delikty, jež ovšem, jak ukazují Chesney-Lind (cit. In Renzetti, Curran, 2005), odrážejí spíše uplatňovaný ,dvojí metr’ na výchovu chlapců a dívek.

Málo tematizovaným aspektem je v souvislosti s,předčasně zahajovaným sexuálním životem ' dívek ověřování proběhlé sexuální aktivity prostřednictvím gynekologické prohlídky. Ta je ze strany DDÚ doporučována umístujuícím instancím ještě před přijetím dívek starších dvanácti let, a to zejména tehdy, existuje-li podezření, že se dívka v době předcházející umístění dlouhodobě či opakovaně zdržovala mimo domov. Případné těhotenství by mohlo být pro provoz zařízení komplikací a pobyt v dětském zařízení by neodpovídal ani potřebám dívky. Jedná se nicméně o viktimizující a ponižující praktiku, které bývá dívka ještě před umístěním vystavena. Ústav sice deklaruje, že na žreteli má zdravotní hledisko dívky, jiná zdravotní rizika spojená se sexuálními aktivitami jsou však přehlížena (různé typy infekcí, pohlavně přenosných chorob).

Shromážděná empirická data tak implikují stereotypy v chápání dívek coby potenciálních matek a sexistické předsudky ve vztahu k dívkám, čímž dochází k jejich viktimizaci, stigmatizaci a etiketizaci nežádoucími nálepkami. Podíl chlapců na sexuálním životě dívek je fakticky zneviditelňován, což odpovídá společenskému stereotypu, $v$ rámci něhož je odpovědnost za sexuální život a sexualitu muže přenášena na ženu. ${ }^{3}$

Pobyt dítěte $v$ systému zařízení pro výkon ÚV a OV je od samého počátku výrazně determinován genderovou kategorií, která je mu přisouzena (gender jako organizační princip, např. Renzetti, Curran, 2005).

Po prijetí do DDÚ Archa je dítě začleněno do výchovné skupiny podle školního zařazení. Skupiny jsou koedukované, takže v průběhu školního vyučování i po dobu odpoledních programů jsou chlapci a dívky $\checkmark$ menších genderově smíšených kolektivech. Na chlapce a dívky se děti striktně dělí ráno a večer ( $v$ době provádění hygieny, přípravy oblečení na další den aj.) a v době spánku.

Výchovná skupina dětí, která je zajištěna dvěma pracovníky/pracovnicemi - mužem a ženou. Opatření je vedeno předpokladem, že je tímto způsobem možné poskytnout dětem mužský a ženský rolový model (koncept nukleární rodiny, např. Giddens, 1999; Možný, 2006). Právě vychovatelé/vychovatelky tráví s dětmi největší časové penzum, takže jejich vliv na utváření genderových rolí u dětí lze oprávněně považovat za nejzásadnější.

„... myslím, že takovej ten mužskoženskej model a to, že něco dělají kluci a něco jinýho holky, je, že tam je nějaká mužská role, ženská role, to třebas v těch bytech je, že to je jako tak hodně prirozený. Asi nejdůležitější je, že tady s nima pracují jak ženský, tak chlapi, co v dětským domově prostě není. Že fakt ta identifikace s tím mužským a ženským chováním... s tím jak oni se chovají mezi sebou..." (zaměstnankyně DDÚ Archa)

Z genderové perspektivy je pozoruhodné zejména nekritické pojímání instituce rodiny vjejím tradičně chápaném pojetí ${ }^{4} \mathrm{~s}$ implicitními heterosexuálními vazbami mezi členy jako modelu pro práci ve výchovných skupinách. Tuto skutečnost dokládá inzerát vyvěšený na internetových stránkách

\footnotetext{
${ }^{3}$ Implicitně přítomné je přitom esencialistické chápání žen/dívek jako homogenní skupiny založené na obecně sdílených charakteristikách, dispozicích, hodnotách či zkušenostech (Uhde, 2004).

${ }^{4}$ Charakteristická je instrumentální role muže a emocionální či expresivní role ženy, implikující distinkci mezi soukromou a veřejnou sférou (více např. Karsten, 2006; Kř́žková, Pavlica, 2004).
} 
zařizení na jaře 2011 (viz obrázek ní̌e, zvýraznění původní), který na první pohled může být vnímán jako snaha posílit reprezentaci zaměstnanců-mužů v organizaci. Stručně rečeno, na úrovni organizace a profesionálního zajištění výchovných skupin v dětském diagnostickém ústavu je reprodukován jak tradiční patriarchální model rodiny (více Havelková, 2004), tak také heteronormativní společenský rád.

\author{
Dětský diagnostický ústav... přijme \\ do komunitního terapeutického systému pro práci s dětmi a jejich rodinami \\ speciálního pedagoga-etopeda (muže) \\ se zařazením do terapeutické dvojice etoped-psycholožka.
}

Obrázek 1. Inzerát dětského diagnostického ústavu na obsazení pozice etopeda-muže (DDÚ Archa, d. a.)

\title{
3.2 Gender „diagnostický“
}

Pobyt dítěte $v$ diagnostickém ústavu je završen dislokací - přemístěním do některého z následných zařízení, resp. do domácího prostředí, a to s ohledem na provedenou diagnostiku. S výraznou dávkou zjednodušení si lze dětský diagnostický ústav představit jako instituci, která tř́dí děti na „hodné“ a „zlobivé“, podle toho je směřuje do „mírnějších“ a „přísnějších“ zařízení a ty nejhodnější posílá domů.

V gesci DDÚ Archa je 30 následných zařízení. Možnosti umístění mají dívky omezenější než chlapci. Tzv. výchovné ústavy (slouží pro děti po ukončení povinné školní docházky) jsou v síti DDú dva pro chlapce a pouze jeden pro dívky. Jeden výchovný ústav je určený pro chlapce i pro dívky. Koedukované dětské domovy se školou (do ukončení povinné školní docházky) jsou tři. Problém s umístěním tak nastává v případě dívek, u nichž je výstupem z diagnostického pobytu rozhodnuto o přemístění do výchovného ústavu, nebot' sít disponuje pouze dvěma zařízeními, přičemž obě se nacházejí v jednom ze dvou krajů $v$ kompetenci daného DDÚ. Lokality jsou to tedy z hlediska dostupnosti pro rodinné př́slušníky/př́slušnice $z$ druhého spádového kraje velmi nevýhodné. Naproti tomu pro chlapce jsou k dispozici výchovné ústavy v obou spádových krajích.

Výzkum ukázal, jak významné je genderové hledisko ve struktuře a zaměření následných zařízení. Genderová segregovanost výchovných ústavů ještě zesiluje zkonstruované rozdíly mezi chlapci a dívkami a jejich genderovými rolemi.

„Já jsem třeba hodně citlivá na to, když v chlapeckém zařizení kluci pletou nebo když se udělá výjezd chlapecký do holčičího zařizení a opačně. Já myslím, že je to nepřirozený. " (zaměstnankyně DDÚ Archa)

Poté, co jsou děti dislokovány do některého ze spádových zařízení, je již z velké části rozhodnuto o tom, co budou studovat po ukončení povinné školní docházky. Výchovné ústavy nabízejí obvykle jeden či dva učební obory. Dítě, které není natolik nadané (a hlavně samostatné a spolehlivé), aby mohlo studovat střední školu v dostupném okolí zařízení, musí nastoupit na učební obor, který otevírá daný ústav. Genderově citlivé výchovné poradenství (Smetáčková, 2007) zaměřené na výkon budoucího povolání, není v systému institucí uplatňováno. Nicméně pro chlapce je nabídka oborů mnohem pestřejší.

Konkrétní nabídka studia v zařízeních $v$ síti studovaného dětského diagnostického ústavu je následující: pro chlapce jsou nabízeny dvouleté obory Provoz společenského stravování, Kuchař, Stavební výroba, Zahradnická výroba a Stavební práce. Jediný koedukovaný výchovný ústav (Vú) umožňuje chlapcům i dívkám studium pouze na jednoleté či dvouleté Praktické škole. Jediný výchovný ústav výlučně pro dívky nabízí dva dvouleté obory: Provoz společenského stravování a Provoz ve zdravotnických a sociálních 
zařizeních. Výběr studijního oboru a potažmo budoucího profesního uplatnění je tak zjevně limitován nejen $v$ důsledku samotného umístění dítěte, ale i z hlediska jeho genderu.

Dívky jsou v systému pro výkon ÚV a OV explicitně znevýhodněny jak z hlediska nižšího počtu disponibilních následných zařízení (a z tohoto důvodu nižší dostupnosti dané lokality pro rodinu), tak z hlediska omezenější nabídky studijních oborů. Stávající situace je v rozporu sideou rovných príležitostí pro ženy a muže. Jak píše Smetáčková (2007), v oblasti školství je klíčové „umožnit každému chlapci a každé dívce, aby rozvíjeli své osobní dispozice a zájmy bez ohledu na genderové představy panující v dané společnosti“ (tamtéž: 67; zvýraznění v originále). Ústavní systém naproti tomu reprodukuje genderové stereotypy týkající se vhodných povolání pro chlapce a dívky, což v praktické rovině uzavírá možnost podporovat všechny studující (tj. dívky i chlapce) ve volbě jakéhokoli povolání.

Zrušením celorepublikově jediného oddělení pro matky s dětmi přestalo být možné dlouhodobější umístění těhotné dívky v dětském domově. Pokud se jedná o dívku, u níž výstupem diagnostického pobytu je doporučení pro premístění do výchovného ústavu, bývá dislokována mimo region do výchovného ústavu pro matky s dětmi. Mimo pozornost ústavní sítě stojí otázka rodičovské odpovědnosti otců uvedených dětí. Ti bývají často také sami svěřenci různých zařízení. O převzetí dílu odpovědnosti se však mnohdy nejedná ani s těmi, kteří v ústavech umístěni nejsou. Častější jsou prípady převzetí péče o dítě matkou či babičkou dívky.

Systém zařízení pro výkon ústavní a ochranné výchovy svým fungováním (re)produkuje rovněž ty genderové stereotypy, které Janebová (2006) tematizuje jako exkluzi otců z rodičovského diskurzu a tzv. mateřský kult (tj. pojímání žen jako expertek na výchovu). Tzv. „genderový kontrakt“ (Hašková, 2000: 7) se tedy projevuje i ve vztahu k dětem, které vyrůstají v patriarchálním modelu rodinných vztahů.

Související otázkou je umožnění ukončení těhotenství umístěným dívkám. Pro provedení zákroku je $\checkmark$ prípadě nezletilých dívek potřebný písemný souhlas jejich zákonné/ho zástupce/zástupkyně. Místo pobytu rodičů umístěných dětí však nezř́íka není známé, často tito rodiče se zařízením nekomunikují, situace je tudíž pro těhotné dívky velmi stresující a komplikovaná. Úhrada zákroku přechází v těchto případech na zařizení, kde se dívka momentálně nachází. Jeho vedení má poté nárok tuto finanční částku na rodičích vymáhat.

V praxi jsou prípady těhotenství dívek posuzovány individuálně, neexistuje žádná závazná koncepce upravující postup pracovníkủ/pracovnic. Pohovoří s ní v každém případě zástupci a zástupkyně zařizení na úrovni psychologické i zdravotní a ponechají jí prostor k rozhodnutí. Svobodnou volbu si však v prostředí ústavu Ize jen těžko představit. Samo umístění v zařizení pro dívku představuje specifickou formu násilí (Bourdieu, 2000; Štech, 2006), které na ní ústav vykonává. Ve vysoce normativním prostředí, kde se dívka neustále prrizpůsobuje a podřizuje pravidlům a je vedena motivem ,vybojovat' si co nejlepší následné zařízení (a již víme, jak omezená je nabídka pro nezletilé matky s dětmi), se svobodná volba stává mizejícím horizontem.

Ústavní systém v sobě dále zahrnuje specifika pro děti s nevyhraněnou sexualitou (či sexualitou vyhraněnou, ovšem mimo normativní heterosexuální orientaci).

Snaha umístit takové dítě do výchovného ústavu (tedy do zařízení s přísnějším režimem) je patrná tehdy, existuje-li anamnestický údaj o sexuálním vztahu dítěte s jedincem téhož pohlaví, a to nejspíše proto, aby mohl být nad sexualitou dítěte vykonáván zvýšený dohled. Můžeme usuzovat, že je v takovém postupu implicitně prítomna myšlenka, že zvýšeným dohledem je možné na sexuální orientaci jedince něco změnit či napravit.

Katz (2002) uvádí, že na konci 19. století začali lékaři předepisovat novou zdravou sexualitu. Byl definován ideál mužsko-ženského vztahu, který zahrnoval jak u žen, tak u mužů esenciální, normální 
erotismus. Z oblasti sexuality se začala vydělovat specifická dimenze "protipřirozeného“ (Foucault, 1999: 48), které během 19. století dostávalo nálepku „morálního šílenstvi“", „genitální neurózy“ či "duševní nevyváženosti“ (tamtéž: 50). V této době vznikla jednak kategorie tzv. moderního homosexuála, jednak nový heterosexuální separatismus - jakýsi erotický apartheid oddělující normální a perverzní sex. Imperativ heterosexuality se ve 20. století dále upevňoval a protikladnost pohlaví se stala základem pro univerzální, normální vztahy mezi ženami a muži (Katz, 2002).

Detailní analýza ukazuje, že snaha umístit dítě do přísnějšího zařízení doprovází do jisté míry i heterosexuálně se projevující chlapce a dívky. Sexuální život vedený kolem 15. roku věku je zřejmě vnímán za znak jakési celkové morální rozvolněnosti, na niž je zapotřebí zvýšeně výchovně působit. Nelze statisticky prokázat, zda je vprípadě dětí projevujících se neheterosexuálně přísnější postup častější, a tudí̌ diskriminační. To proto, že umístění dítěte do následného zařízení je založeno na více důvodech. Co však je společné heterosexuálním i neheterosexuálním aktivitám umístěných dětí, je tendence je mapovat a dokládat v písemných anamnestických záznamech jako informaci relevantní pro celkové posouzení perspektivy dítěte.

Slovy Michela Foucaulta (2003) jde o potřebu vědět, aby bylo možné uplatnit moc. Na druhou stranu, pokud se neheterosexuální zaměření dítěte profiluje pouze ve formě „platonické“, je zřejmá potřeba DDÚ dítě „ochránit“ před agresivními projevy (zejména) heterosexuálního chování ze strany jiných dětí. Při dislokaci se dává přednost koedukovaným zařízením mírnějšího typu. Hoagland (in Pavlík, 2002) hovoři o dynamickém vztahu ochránce-dravec, který je součástí konceptu hegemonní maskulinity. Zdá se, že podobné principy Ize identifikovat voblasti sexuálního chování homosexuální projevy jsou konstruovány jako vyžadující speciální ochranu před sexuálními dravci, bez ohledu na jejich sexuální orientaci.

\subsection{Gender „historický“}

Sociálně-kulturní podmíněností jednotlivce $v$ proměnách času se patrně nejintenzivněji zabývá historická antropologie. Její výchozí premisou je vyloučení jednotného a uzavřeného dějinného obrazu člověka. Ten je utvářen v rámci historického procesu (van Dülmen, 2002).

Uvedená teze prímo rezonuje svýchodisky feministických teorií, které zpochybňují pojetí genderových kategorií včetně jejich rolových obsahů jako ahistorických. Na historičnost pohlavněgenderového systému upozorňuje například Havelková (2004). Zatímco ve feudální společnosti byli muž i žena stejně bezvýznamní nevolníci, oba stejně museli $v$ zájmu přežití pracovat na výrobě a jejich role byly do značné míry vzájemně zastupitelné, v moderní měšt́anské společnosti je již budoucnost člověka předurčena skutečností, zda se narodil jako muž, nebo jako žena (tedy pohlavněgenderovou př́slušností). Optikou historické antropologie, jakož i optikou feministických teorií můžeme genderový kontrakt a s ním spojenou polarizaci genderových rolí označit za poměrně nový jev, ke kterému dochází někdy na počátku 19. století v tzv. západních společnostech.

Z hlediska konkrétních oblastí, kterými se zabývá historická antropologie, genderová studia a současně má výzkumná studie, je patrně nejvýznamnějším a zřejmě také nejilustrativnějším ve smyslu demonstrace podobností a rozdílu různých perspektiv téma rodiny. Představy o funkci a smyslu rodiny jako instituce hrají významnou úlohu při analýze a interpretaci empirického materiálu nashromážděného v DDÚ Archa. Nukleární rodina upevňující dvoupohlavní model vztahů mezi mužem a ženou se v prostředí náhradní výchovy stává předobrazem „zdravých“ mezilidských vazeb.

„Veškerá zařízení jsou vícerodinná. To znamená, že... tam jsou jako rodinné buňky, jednotlivé byty. Že se to více podobá tomu domovu. Některý zařizení... tam je více dětí pohromadě. Ne ani pohromadě, ale to zařizení je vícepočetný, ale myslím, že to tam není moc jako doma, taková rodinná. Když je to více roztřištěné $v$ těch bytech nebo skupinách jakoby s nižším počtem dětí, tak je to jakoby myslím více 
rodinný no. No a pak jsou ty dětské domovy se školou, že jo. To je zařizení, který teda pracuje s dětma, které mají větší výchovný problémy. Tam je to už asi spíš více o tom režimu, než o té rodině. ... Pokud zařizení, ty dédéešky (zkratka DDŠ - dětský domov se školou, pozn. aut.) nepracují s rodinama, tak se to nemá kam posunout." (zaměstnankyně DDÚ Archa)

Je-li gender historický a představa o mužské a ženské roli se proměňuje napříč dějinami, pracovníci/ice "třídících institucí" vštěpovali a vštěpují obrazu "hodného dítěte" různé genderové charakteristiky $v$ různých údobích - dle kurikula odborných disciplín, společenských norem či individuálních představ. Mění se však nejspíše obsah, nikoli forma. Co zůstává, je princip diagnostické instituce, která měří, počítá, pozoruje, hodnotí, kvalifikuje a uplatňuje genderovou disciplinaci jako součást nápravné výchovy. Nastoluje vlastní pravidla, v nichž je zapotřebí obstát. $\mathrm{V}$ režimu pravdy (Foucault, 1980) vytvořeném diagnostickým ústavem je úspěšným ten, kdo si tato pravidla byt' jen účelově osvojí.

\subsection{Gender „pomáhajíci“}

Existuje nepřeberné množství disciplín, na jejichž pozadí lze studovat gender a jeho re/konstrukce. Není však již tolik vhodných empirických prostředí, která by svou povahou byla tak mnohostranně a mezioborově využitelná, jako je instituce pro výkon ústavní a ochranné výchovy. DDÚ v sobě zahrnuje odbornost sociální práce, vychovatelskou, psychologickou, etopedickou aj. Souhrnně jsou tyto disciplíny někdy označovány jako pomáhající profese. Jejich cílem je přijímat každého člověka $v$ jeho jedinečnosti, respektovat individuální odlišnosti a přispívat k osobnostnímu rozvoji (Matoušek a kol., 2001).

Na druhé straně právě pod záštitou pomáhajících profesí dochází často $\mathrm{k}$ manipulaci a disciplinaci klientů a klientek, a to $v$ zájmu jejich ,normalizace', tj. přizpůsobení normám majoritní společnosti (např. koncept sociálního fungování v rámci tradiční sociální práce; srov. Sheafor, Horejsi, Horejsi, 2000 aj.). Dvojznačné postavení těchto disciplín je reflektováno $v$ hojně citovaném etickém dilematu ,pomoc/kontrola' (Úlehla, 2005; Musil, 2004). ${ }^{5}$ Méně zájmu je však již věnováno jednotlivým kontrolním a disciplinačním praktikám uplatňujícím se v konkrétních institucích. Limitující roli mủže hrát problematický př́stup do nitra těchto institucí (tzv. gatekeeping; srov. Hammersley, Atkinson, 1995: 63).

Vzhledem k tomu, že na konstrukci genderových identit, kategorií a rolí se ve studovaném DDÚ Archa podílejí zejména pracovníci a pracovnice z oboru vychovatelství, psychologie či speciální pedagogiky, je tedy legitimní se ptát, jak se promítají diskurzy tzv. pomáhajících profesí do konkrétních praktik genderové disciplinace, knimž dochází v každodenní realitě systému úV a OV a jaký mají tyto diskurzy podíl na legitimizaci mocenských praktik a produkci genderu v ústavním prostředí.

Výstupem shrnujícím pobyt dítěte v DDÚ Archa je tzv. závěrečná zpráva. Je tvořena posudky celkem šesti odborností - šesti pomáhajících profesí: sociální, vychovatelskou, pedagogickou, zdravotní, psychologickou a etopedickou. Zpráva tak do značné míry ztělesňuje "archiv“ ve foucaultovském významu (Foucault, 2002). Přestože právě Foucault nenahliží na archivy jako dokumenty skrývající významy, nýbrž jako jakýsi obecný systém výpovědí v rámci určitého diskurzu, a v logice této argumentace by se za archiv dal považovat spíše DDÚ Archa, závěrečná zpráva je pro svou diskurzivní transverzálnost reprezentací tohoto archivu. Jakýmsi předobrazem zprávy jsou průběžné poznámky o dítěti, sdílené např́čc všemi odbornostmi v DDÚ Archa formou elektronického software. Do př́slušné kolonky je možné vložit poznámku o chování dítěte během dne, jeho dotazech, návštěvách príbuzných, absolvovaných psychologických

\footnotetext{
${ }^{5}$ Za zamyšlení v této souvislosti stojí otázka smyslu označení ,pomáhající profese', jež evidentně čerpá jen z prvního jmenovaného způsobu intervence, kterým je ,pomoc'. Druhý legitimní způsob práce s klienty/kami je v názvu upozaděn. Spojení ,pomáhající profese' evokuje představu solidarity, dobročinnosti a sounáležitosti. Označení ,kontrolní profese' by mělo podstatně jiné konotace a odkaz na ,poslání' či ,službu lidem' by v zásadě nebyl možný. Touto optikou se upozadění ,kontroly‘ může jevit jako strategická diskurzivní manipulace.
} 
testech, prohřešcích aj., včetně osobních interpretací uvedených projevů pracovníky/icemi. Postupně se tak zakládá archiv vědění, ze kterého je čerpáno při zhotovování závěrečné zprávy, ale především, který spoluvytvárí obraz identity dítěte v DDÚ Archa. Cílem závěrečné zprávy z diagnostického pobytu je tedy sumarizovat vědění. $A$ vědění zakládá moc.

Na význam pedagogicko-psychologického diskurzu pro fungování nápravných institucí upozornil Foucault (2000), který v tomto kontextu hovoří o „zrodu vědecké psychologie“ (s. 408), jejíž moc/vědění pomáhá zajištovat vládu univerzálnosti normy.

Když se dítě ptá, zda bude propuštěno domů, zpravidla je mu odpovězeno, že o tom rozhoduje soud. Ten si ke svému rozhodnutí vyžádá psychologickou či etopedickou zprávu (zde se ukazuje, jaký diskurz obíhající v DDÚ je nejvlivnější), která obsahuje i doporučení, zda dítěti zrušit (resp. nenařídit) či nezrušit ústavní výchovu. O tom, jak moc důležitá je zpráva psychologa/žky pro jejich další osud, jsou děti velmi často informovány. Jedná se o jeden z klíčových mocenských nástrojů.

\subsection{Gender „institucionální“}

Na DDÚ Archa je možné pohlížet jako na jedinečný a svébytný prostor, v němž platí specifická pravidla, která ovšem nemusejí být sdílena ostatními institucemi v rámci systému pro výkon úV a OV. $\checkmark$ následujícím výkladu jde o zachycení těchto interních mocenských praktik a o uplatnění kritické genderové analýzy v konkrétních sledovaných aspektech každodenního fungování vybrané instituce náhradní výchovy.

\subsubsection{Program}

Goffman (1961) v souvislosti s totálními institucemi popsal, jak mohou být běžné jednoduché denní aktivity, jako je například oblékání, rozděleny do načasovaných úseků, přičemž jakákoli odchylka od předepsaného časového plánu je spojena se sankcemi (srov. též Kivett, Warren, 2002). Foucault (2000) podobně hovoří o jakémsi rozvrhu hodin, podle kterého se dílčí denní činnosti řídí. Moc rozptýlená v DDÚ Archa je tak schopna získávat př́stup $k$ tělům jedinců, a $k$ jejich jednání v každodenním životě (Foucault, 1980: 125). Institucionalizovaná disciplína pak úspěšně činí $z$ dětských těl objekty komplexního systému manipulace a kondicionace.

V DDÚ Archa je načasován průběh celého dne, s malými rozdíly pro všední a víkendový den (ten je z hlediska režimu uvolněnější). Předepsáno je, kdy probíhají denní jídla, ranní a večerní hygiena, úklidy pokojů, terapeutické skupiny s psychologem/žkou a etopedem, telefonáty s blízkými osobami či kdy je možné využívat volný čas. I volný čas je ale permanentně pod dohledem (gaze, Foucault, 2000) dospělé/ho pracovníka/ice DDÚ. Záleží na jeho/jejím posouzení, zda umožní dětem např. psát si o samotě na pokoji dopisy. Souvisejíć mocenskou praktikou je $v$ prípadě DDÚ Archa například nutnost vést telefonické rozhovory $s$ rodinou výhradně $v$ českém jazyce, aby jim rozuměl prítomný personál. Explicitně znevýhodněno je tím nezanedbatelné procento romsky hovořících dětí. Striktní načasování programu se týká $i$ týdne jako časové jednotky - v pondělí po obědě je komunita, $v$ úterý dislokace, $v$ pátek po obědě celkové hodnocení, v neděli většina návštěv apod.

Program pro děti není výrazně genderově strukturován. Dívky i chlapci chodí do kina a do divadla na stejná představení, na stejné akce do městských institucí. I v př́padě návštěv sportovních utkání jsou vybírány genderově smíšené skupiny dětí. Hlavním kritériem nominace není gender, nýbrž aktuální hodnocení chování dítěte.

Jedním z mála genderových rozdílů v programu je zvýšené zapojení chlapců do sportovního vyžití v rámci zařízení. Předpokladem je, že takto mohou snáze odčerpat agresi (na rozdíl od dívek) a docílit pozitivních změn v chování. Sporty, kterým se děti v DDÚ Archa věnují, jsou totiž v tuto chvíli plošně nastavené tak, aby vyhovovaly spíše silově a výkonnostně zdatnějším jedincům. 


\begin{abstract}
„Řekla bych možná v tom i ty holky nemaji tolik toho sportovního vyžití, jakoby speciálně pro holky... myslím, že prostě je to zahrnutý v tom, že co je pro ty kluky, i holkám vyhovuje, jo. Já si myslím, že třeba ten aerobik některý ty holky by privítaly, což si myslím, že tam tak není. Že třeba pro kluky je tam hodně fotbal... myslim z toho sportovního vyžití jo... kolečkové brusle, kolo jakoby výlety jo... třeba tohleto zaměřeni, třeba tanečni kroužek. "(zaměstnankyně DDÚ Archa)
\end{abstract}

\title{
2.5.2 Rituály
}

Speciální význam mají pro život DDÚ Archa pravidelně se opakující programové komponenty, tzv. rituály. Rituál je předmětem studia kulturní antropologie (např. Geertz, 2000), jakož i zmiňovaných pomáhajících profesí (Kaufmann-Huber, 1998). Patrně nejčastěji se v souvislosti se zavedenými rituály v DDÚ Archa zmiňuje snaha ukotvit děti v bezpečném prostoru, poskytnout jim hranice a nabídnout způsob, jakými utužovat vztahy - pomocí zprvu umělého systému nastartovat zvnitřnění mechanismů pro úspěšný život mimo zařízení.

Jedním z klíčových rituálů života v DDÚ Archa je tzv. „komunita“, která se koná pravidelně každé pondělí po obědě. Jejím cílem je přivítat děti, které nastoupily za uplynulý týden; rozloučit se s dětmi, které v následujícím týdnu zařizení opustí z důvodu přemístění do následného zařízení či propuštění do domácího prostředí; poblahopřát dětem, jež v daném týdnu slaví narozeniny, a obdarovat je dárečky; ocenit děti, které učinily významný pokrok v chování a motivovat je tak k další „práci“. Prostor je i na dotazy a prípomínky dětí, pochvaly, rozloučení, stižnosti apod. Komunita je vždy vedena dvojicí ředitel/ka zařízení zástupce/kyně ředitele/ky. Rituální charakter komunity je posílen dogmaticky dodržovaným scénářem, jenž nabývá jen minimálních rozdílů mezi jednotlivými týdny. Zařazovány jsou rovněž vždy stejné písně na rozloučenou a na privítanou, jež jsou kolektivně zpívány. Pole pro kritickou genderovou analýzu skýtá zejména píseň na uvítanou:

„Zpiváme novým dětem, každý z nás tu taky takhle stál.

Vítáme Tě v dětském světě, ne aby ses tady pral, to tedy ne.

Staň se naším kamarádem a měj nás tady všechny rád.

Hezky pracuj, nebud' kůže líná, my jsme jedna velká rodina."

Přítomné generické maskulinum se v podobných př́padech ospravedlňuje argumentem, že mužský rod je přece univerzální a zahrnuje v sobě muže i ženy (Valdrová, Knotková-Čapková, Paclíková, 2010). Pokud ale píseň navíc zakazuje pranice, v naší společnosti tradičně spojované s chováním chlapců, pak se okruh osob, ke kterým fakticky promlouvá, výrazně zužuje. Za pozornost jistě stojí apel k posílení vztahu dítěte sostatními dětmi a dospělými $v$ DDÚ a rovněž prohlášení jednoty v podobě metafory "jedné velké rodiny“. Do obrazu rodiny má však život v DDÚ poměrně daleko a navíc je to právě personál, který argumentuje profesním cílem ozdravení vazeb dítěte s původní rodinou.

„Není to třeba jejich problém, ale je to... Já bych řekla, že převážně tam chodí děti, že to jejich problém úplně není, ale že to je problém $v$ těch rodičích nebo v té rodině prímo... řekla bych, že u nás je ten kontakt s rodinou hodně podporovanej. Že od začátku, pokud se nikdo neozve, tak se snažíme nakontaktovat, snažíme se je podporit, pouštět je na nějaké vycházky, výlety. Pokud prijedou rodiče, děti pouštět. Řekla bych, že i u nás se snaží s nima pracovat, promlouvat, jak na to, co s dítětem, aby se to zlepšilo. Ne každý zařizeni podporuje vztahy s tou rodinou. "(zaměstnankyně DDÚ Archa)

Zaměřme se ale ještě na druhou stránku rituálů a ritualizovaného chování. Ta má totiž významně blízko k tzv. režimu DDÚ Archa a k aspektu časování a krokování jednoduchých denních úkonů, popsaných výše (Goffman, 1961).

Jako ilustrativní přiklad poslouži pohyb dítěte v rámci výchovné skupiny po budově zařizení. Jeho cesta z jídelny na pokoj je přerušena pokynem $k$ seřazení do zástupu nejméně třikrát. Poprvé těsně za dveřmi jídelny, podruhé jen o několik metrů dál pod prvním schodištěm, následně nad prvním schodištěm 
(prípad divčího patra), event. pod druhým schodištěm a na jeho konci na chlapeckém patře. Pokud se zástup dětem nepodaři utvořit svižně, v klidu a bez nežádoucích projevů v chování dle posouzení konkrétni/ho vychovatele/ky, je svoláván opakovaně. Disciplinace tohoto druhu je prímo vtělena do prostoru. Místa rituálního svolávání nástupu by Foucault nejspiš nazval ohnisky moci (1980). V termínech sociologie bych je označila za uzlové body kontroly, které systém podepírají. Ty v prostředí DDÚ Archa evidentně operují nejen v čase, ale i v prostoru.

Uvedený jev Ize interpretovat na podkladě Foucaultova konceptu disciplinace (2000). Autor rozlišuje mezi diskurzivními formacemi, kterými rozumí určitý režim řeči, tj. výpovědi, jež jsou $v$ daném diskurzu považovány za pravdivé ( $v$ kontextu DDÚ Archa např. teze „děti potřebují hranice"), zatímco nediskurzivní formace se vztahují $k$ tomu, co je viditelné. $V$ prípadě vězení je to kamenná stavba, která má videálním př́padě podobu Panopticonu (Bentham cit. in Foucault, 2000: 282). Od Panopticonu odvozený efekt strážní věže, neboli panopticismus, spočívá dle Foucaulta (2000) $v$ naprosté viditelnosti jedinců za neviditelnosti strážce. Jedinci tak podléhají všudyprítomnému působení moci, aniž by věděli, kde a v jakém okamžiku jsou právě sledováni. V DDÚ Archa se může jednat o hierarchické architektonické uspořádání, úzký zamykatelný koridor spojující budovu DDÚ s budovou školy apod. Princip Panopticonu je ve výzkumném prostoru navíc promyšleně genderován.

\subsubsection{Adaptace}

Na počátku pobytu vDDÚ Archa získává každé dítě určitý oddechový čas - čas na adaptaci, seznámení se s pravidly režimu, budovou i jednotlivými pracovníky a pracovnicemi. Období trvá tři dny, kdy dítě ani neopouští areál zařízení formou vycházek se skupinou.

Goffman (1961) by adaptační fázi v DDÚ patrně nazval „vstupními momenty socializace“ (s. 17). Jenže jedinec není socializován pro život ve společnosti, jak by se z pojmu mohlo zdát. Je socializován pro život v umělém prostředí diagnostické laboratoře - osvojuje si pravidla jiného světa, než je ten, k němuž se dříve či později vrátí. Optikou kritické analýzy lze usuzovat, že pokud se dítě v DDÚ naučí, že dívčí a chlapecký svět funguje zásadně jinak, pro obě pohlaví platí jiná pravidla a život dívky/ženy je zatěžkán větším objemem pravidel, přičemž tak je to v pořádku a jiné uspořádání zasluhuje sankce, je do svého skutečného života vysláno s poselstvím, že genderová nerovnost je normou a údělem.

\subsubsection{Prostorové uspořádání}

Patra DDÚ Archa jsou od sebe odlišena barevně. Chodby na dívčím patře jsou vymalovány žlutě, jakož i pokoje dívek. V oknech visí žluté záclonky, povlečení je laděno do žlutých a oranžových odstínů. Naopak chlapecké patro je vymalováno zeleně, vybavení pokojů má zelené odstíny, a to včetně nátěru nábytku. Posilovna se nachází na chlapeckém patře, čímž je implikována stereotypní představa, že fyzické cvičení za účelem posilování svalové hmoty je „mužskou záležitostí. ${ }^{6}$ Nezanedbatelný je rovněž aspekt vertikálního uspořádání budovy - dívčí pokoje se nacházejí v prvním patře, chlapci mají své pokoje $\checkmark$ poschodí druhém. Na symbolické úrovni může toto uspořádání implikovat určitou hierarchii vztahů mezi dívkami a chlapci.

Vztahy nadřazenosti a podř́zenosti jsou tak analogicky ke konceptu somatizace nadvlády (Bourdieu, 2000) materializovány či architektonizovány, tedy vepisovány do prostorového uspořádání budovy, přičemž toto uspořádání se podílí na udržování genderově podmíněných mocenských vztahů. Architektonické uspořádání z hlediska genderu skýtá prostor pro další možné interpretace. Jednou z nich je stereotypní vnímání chlapců jako fyzicky zdatnějších. $V$ souladu s touto představou se může

\footnotetext{
${ }^{6} \mathrm{~V}$ souvislosti s umístěním posilovny na chlapecké patro Ize vyvozovat možný vztah zelené barvy k vojenství a armádě. Pro detailnější rozbor například účinků barev na psychiku není prostor, Ize ovšem odkázat na některé dílči studie (Goethe, 2004), podle nichž zelená barva působí uklidňujícím dojmem (chlapci jsou genderově stereotypně pokládáni za živější, divočejší, impulzivnější), zatímco žlutá aktivizuje a energizuje. Žlutá nebo oranžová mohou také asociovat, teplo krbu' a odkazovat k archetypu ženy - strážkyně ohně (více Pratt, 1981).
} 
jevit jako ,galantnější přenechání nižšího patra dívkám. V rámci seminárních skupin při výuce na KGS se autorka setkala s dalším alternativním výkladem: Umístěním do vyššího patra může být chlapcům, kteří jsou obecně považováni za divočejší, ochotnější k překračování hranic a nebojácnější vůči riziku (Renzetti, Curran, 2005), ztížena možnost útěku.

\title{
2.5.5 Vnitřní předpisy
}

Hodnocení chování dětí v dětském diagnostickém ústavu je založeno na bodovém systému, který je blí̌ze specifikován ve vnitřním řádu zařízení (Vnitřní řád DDÚ Archa). Plusové (červené) body jsou dětem udělovány za konformní chování a jsou spojeny s určitými výhodami (např. volné vycházky bez dozoru vychovatele/ky). Černé naopak následují po některém z prohřešků, vyjmenovaných ve vnitřním řádu (Vnitřní rád DDÚ Archa). Kivett a Warren (2002) tento systém nazývají „token economy" (s. 6). V jejich výzkumu vyšlo najevo, že chlapci ve výchovném zařízení body nedostávají, ale sami si je zapisují do sešitků, které nosí stále při sobě. $V$ DDÚ Archa funguje bodový systém obdobně - děti si udělené body během dne pamatují a v určenou dobu si je nahlašují (veřejně, tj. před celou skupinou).

„Ty děti si to pamatujou. A většinou si pamatujou, co je dobrý. A náhodou někomu se stane, že si neřekne teda to, co je špatně, a může mu to projit. Ale když mu to neprojde, tak vlastně má jakoby podvod. A probírá se to. Ale je na tom dítěti, co si riskne a jak to tady odhadne. Takže naprosto prirozená situace, která je kdekoli jinde, a zase to ti vychovatelé s tím dítětem probírají. Že to není technokratická zbraň." (zaměstnankyně DDú Archa)

Na pozadí bodového systému hodnocení se profilují dva speciální instituty - tzv. zákaz výhod a „Vzorňák". První jmenovaný je stavem, do něhož se dítě dostává při převaze „černých” nad „červenými". Vzorňák nastává při situaci opačné.

\begin{abstract}
„Ale myslím, že nestojíme, ani to tady není nastavený tak, že by ti vzorňáci měli nějaký supervýhody. Prostě kapesný je stejně stanovený stejně vysoko jako pro ty, co nejsou vzorňáky, spišs se jako odebírá těm, který jsou jako teda v zákazu, a v zákazu musí být, protože my musíme nějak stanovit odchylku od těch norem, a ty děti musej k tomu mít respekt, a to je zase postavený na těch vztazích." (zaměstnankyně DDÚ Archa)

„[Když jsou děti v "zákazu”, tak nesmí] nosit svoje oblečení třeba, nosit ozdoby, ňáký šperky, peelingy, malovat se, ... lícit se, televizi asi jo, já nevim úplně přesně, podle mě jo, pak třeba i jet domů jo, mají nárok na základní jídlo, [nesmí si přidat]." (zaměstnankyně DDÚ Archa)
\end{abstract}

Za pozornost stojí ,prohřešky', které jsou v souladu s vnitřním řádem ohodnoceny třemi, resp. pěti černými body: „sexuální aberace infantilního rázu - osahávání a obnažování se na ložnicích u malých dětí; sexuální aberace homosexuálniho rázu, sexuální násilí, zneuživání menších a slabších děti" (Vnitřní řád DDÚ Archa; zvýraznění autorka).

Sexuální projevy infantilního a homosexuálního charakteru jsou zjevně vnímány jako nežádoucí, nebot' jsou explicitně trestány černými body. Potom je ovšem pozoruhodné, že podobný bodový postih nenásleduje tehdy, pokud se sexuální projevy vyskytnou napríklad u heterosexuálně zaměřených dětí mladších patnácti let. Přitom důsledky heterosexuálního kontaktu mezi dětmi mohou být, pragmaticky vzato, pro zařízení závažnější (např. nežádoucí otěhotnění). Vnitřní ŕád navíc vůbec nezohledňuje období sexuální nevyhraněnosti (Smetáčková a kol., 2008). Namísto toho rétorikou 19. století odkazuje $\mathrm{k}$ represivním opatřením (trestné body), jejichž cílem je udržení heteronormativního řádu (Foucault, 1999).

Promluvy respondentů/ek na druhé straně opět odkazují k často zmiňovanému vztahovému rozměru práce vDDÚ Archa - jenž v sobě nicméně nadále implicitně stvrzuje heteronormativitu a potřebu dohledu (Foucault, 2000). 


\begin{abstract}
„Tak myslím si , že tady je hodně príležitostí, jak to děti vidí, jak se s k sobě my chováme dospěláci, že jsou tady ženské i muži apod. a že taky to zjemňujeme a taky samožrejmě oni si sem choděj se nějakýma způsobama z domova a my snima bud' souhlasíme a podporujeme je, a nebo snima nesouhlasíme a někde to brzdíme. Takže jako zamilovat a psát si psanička je tady asi naprosto běžný. Pomáhat si a podobně a myslim si, že i se můžou někde, když si najdou nějakou situaci, že můžou jít do nějakých větších intimností, ve smyslu dát si někde pusu, někde možná na sebe sáhnout. A to asi tak nějaká ta hranice, kterou teda jsem ochotný tolerovat. A určitě tady nemůžou být nějaký další intimnosti, že by tady někdo měl mezi sebou sex nebo že by tady někdo osahával nějaký malý dítě proti jeho vůli a podobně." (zaměstnankyně DDú Archa)

„Ale jinak si myslím, že ty trampoty i u sexuálně akcelerovanýho vývoje zjemňovat životem s tím druhým pohlavím, a teda pod dohledem nějakých odborníků a teda monitorováním nějakýho společnýho života." (zaměstnankyně DDú Archa)
\end{abstract}

Gray (2007) došla k zjištění, že mladí lidé identifikující se jako queer díky svým zkušenostem s vlastní sexuální identitou ve školním prostředí doslova „psychicky strádaji“ (Gray, 2007: 123). Dopady působící heteronormativity, homofobie a normativní binarity lze předpokládat rovněž v prostředí DDÚ. Marginalizace LGBT dětí je navíc umocněna klíčovým aspektem permanentního umístění v zařízení, které omezuje možnosti dítěte ve všech oblastech jeho života (kulturní, ekonomické, zájmové činnosti aj.).

Vnitřní řád dětského diagnostického ústavu obsahuje rovněž genderově segregující předpisy ve vztahu k denním aktivitám. Ranní a večerní režimy dětí probíhají odděleně pro chlapce a pro dívky, nebot' se odehrávají zvlášt v prvním patře, kde jsou ubytovány dívky, a zvlášt́ ve druhém patře, kde jsou pokoje chlapců. Pro dívky navíc existují speciální předpisy a pravidla, která se chlapců vůbec netýkají (viz níze $v$ textu).

Tato praxe se někdy označuje jako "doing gender" (West, Zimmerman, 1987: 125). Dělat gender podle dvojice autorů znamená vytvářet rozdíly mezi děvčaty a chlapci a ženami a muži. Jde o rozdíly, které ovšem nejsou přirozené (biologické). Nicméně poté, co byly jednou zbudovány, jsou využívány k podpoře esenciality genderu. Navíc jsou ponejvíce zdůrazňovány a dále reprodukovány jen určité, tzv. ideální genderové charakteristiky (srov. Nagl-Docekal, 2007). Konkrétní způsoby, kterými se ústavní zařizení podílí na posilování představy esenciální rozdílnosti dívek a chlapců a které vedou k reprodukci tradičních obrazů maskulinity a femininity, dokumentuje i následující výňatek z Vnitřního řádu DDÚ Archa:

\title{
Buzení dětí - ranní režim
}

Po probuzení si děti ustelou postele (deku, polštář a prostěradlo si děti uloží do šuplíků pod postelí). Dívky si vezmou župany... Potom si děti společně nastoupí na hale (dívky) a na chodbě (chlapci), kde asistent pedagoga (pečovatel) zkontroluje zevnějšek dětí, kapesníky, ponožky apod. Do školy chodí dívky v sukních, není-li na komunitě rozhodnuto jinak. Společně odcházejí do jídelny. Po snídani předává asistent pedagoga (pečovatel) jednotlivé skupiny učitelům.

\section{Malování dívek}

Dívky se malují, jsou-li starší 12 let; nejsou-li v ZV, ${ }^{7}$ mají vlastní šminky; malují si jen řasy a linky; nedělají si stíny. Vhodnost posoudí vždy dospělý.

\section{Depilace dívek}

Dívky se depilují, jsou-li starší 13 let; nejsou-li v ZV; pouze po svolení dozor konající vychovatelky; dívky se depilují pouze $v$ pátek nebo sobotu.

\section{Barvení dívek}

\footnotetext{
7 Jedná se o zkratku pro institut tzv. ,zákazu výhod'. Do zákazu výhod se dítě může dostat například za výrazně špatné hodnocení chování za uplynulý týden, za pokus o útěk či zrealizovaný útěk. Zajímavé je navázání hodnocení chování na možnost či nemožnost zdobení vlastního zevnějšku. Jde navíc o genderově specifické pravidlo - týká se pouze dívek.
} 
Dívky si mohou barvit vlasy pouze, jsou-li starší 15 let; nejsou-li v ZV; mají písemný souhlas rodičů, ${ }^{8}$ mají svoji barvu na vlasy; se souhlasem dozor konající vychovatelky; pouze $v$ pátek nebo sobotu. Za účelem barvení vlasů si dívka zajistí v prádelně starý ručník. (Vnitřní řád DDÚ Archa).

Například pouze pro dívky platí povinnost oblékat si při ranních režimech župan. Pravidlem explicitně neuvedeným ve vnitřním řádu, leč v praxi uplatňovaným, je povolená frekvence mytí vlasů jedenkrát za týden, častěji pouze se svolením vychovatele/ky.

„Řekla bych, že holky dbají zvýšenějc na tu hygienu a to si myslím, že to tady taky moc neodpovídá těm potřebám. Mytí hlavy, jak kdo potřebuje, ne to mít naplánovaný. Otázka je zase financí, že, mycí prostředky a tak... myslím, že je to ten důvod, proč to není, protože jak se všechno zdražuje, tak se snaží šetřit $v$ rodinách a tak se snaží šetrit i tady..." (zaměstnankyně DDÚ Archa)

Dívky nemají v době menstruace u sebe hygienické potřeby, musí si je vždy vyžádat u své vychovatelky/vychovatele. Jiným specifikem pro dívky je povinnost chodit do školy v sukni. Školní výuka trvá obvykle do 13.30, poté již smějí být oblečeny i v kalhotách. Pravidlo nošení sukní se vztahuje na všechny dívky bez rozdílu, bez ohledu na roční období. Výjimky se povolují zřídka, např́klad pokud je děvče momentálně nachlazené. Jiným žádostem dívek, že sukni obléknout nechtějí (např. z důvodu menstruace, studu, nepohodlí či jednoduše proto, že nejsou zvyklé sukni nosit), se nevyhovuje. Sukně mají dívky na výběr v různých provedeních, ale nesmí být nošeny bez punčocháčů, at' už silonových nebo pletených.

Pravidlo povinného nošení sukní se opírá o následující nepsanou filozofii: Dívky, a to i ty, které např́iklad $v$ důsledku svého dosavadního způsobu života $v$ tísnivých existenčních a sociálních podmínkách, nikdy neměly sukni na sobě, nyní mají možnost si vyzkoušet svou tradiční ženskou roli, nechat rozvinout svůj přirozený šarm, získat tak nové (dívčí) sebevědomí. Je zde i možnost rozpuštění určitých psychických obran, které se mohou projevit právě maskováním dívčí identity do chlapeckého vzhledu - tedy včetně chlapeckého oblečení. Uvedená filozofie není součástí vnitřního řádu a není mi známá ani jiná písemná dokumentace DDÚ, která by pravidlo nošení sukní zahrnovala a zdůvodňovala.

„... My tady máme jednu zvláštnost a to je to, že holky nosí do školy sukni. A to je jedna výborná věc, protože to je taková bezpečná plocha, kde ty holky třeba řikají, fuj, takovouhle hnusnou sukni nosit nebudu atd. a spousta agrese se tam odčerpá. Co oni teda nechtějí prijmout, protože málokterá z nich nosila sukni, ale odpoledne už můžou být v kalhotách stejně jako o víkendu. Ale právě při tom, když mají tu sukni, tak opouštějí to takový to bezpečný klučičí chování, kdy jim jakoby mủže být všechno tak nějak jako jedno. Dochází tam ktomu, kdy jako takhle prijímají takovou tu ženskou roli..." (zaměstnankyně DDÚ Archa)

Z genderového hlediska se jedná o cílené zdůrazňování rozdílnosti obou pohlaví (Thorne, 1978). Filozofie se opírá o předpoklad, že každá bytost se vyznačuje jakousi esenciální přirozeností, která má být a je rozpoznatelná na základě „zjevných přirozených znaků, které vykazují nebo kterými se projevuji“ (Goffman, 1976: 75). Femininita a maskulinita jsou pak považovány za „prototypy esenciálního projevu" (tamtéž). Na základě nekriticky přijímaného biologického determinismu v DDÚ dochází k stereotypnímu konstruování obrazu ženství, kdy jsou mu přisuzovány tradičně ženské atributy („přirozený dívčí šarm“). V DDÚ Archa tak na podkladě konzervativního přesvědčení, že ,správná dívka je dívka v sukni', dochází k poměrně nevybíravé disciplinaci dívek. Konkrétní používaná metoda je do značné míry ideologická ve smyslu pokřivení významu a obsahu genderových identit a rolí. Karsten (2006) hovoří o tzv. diskriminační výchově k genderovým rolím.

\footnotetext{
${ }^{8}$ Toto pravidlo může být chápáno jako implicitně znevýhodňující ty dívky, jež rodiče nemají nebo jejichž rodiče s ústavem nejsou (nebo nemohou) být v kontaktu.
} 
Z výzkumných rozhovorů vyplynulo, že ne všichni zaměstnaní jsou o správnosti opatření v podobě povinné sukně pro dívky přesvědčeni. Nicméně představa o potřebě výchovy $k$ dichotomizovaným genderovým rolím přetrvává i u kritiků/ček tohoto opatření.

„Já si myslím, že sukně dívku nedělá. Já si myslím, že je to v něčem jiným. Že by se ta holka měla spíš naučit chovat jako holka, prostě se nějak projevovat, ale prostě si myslím, že v té sukni to úplně není." (zaměstnankyně DDÚ Archa)

Zvlášt́ jsou ve vnitřním řádu upraveny veškeré zkrášlovací procedury, jež jsou nedílnou součástí života většiny dospívajících dívek, ale i chlapců. Předpisy týkající se líčení, holení či barvení vlasů jsou však adresovány výhradně dívkám.

Zjevná je tendence dívky při jejich aktivitách kontrolovat, byt' jde o pouhé holení nohou. Navíc, čím více pravidly je život dívek v zařízení upraven, tím větší je pravděpodobnost porušení některého z nich, tedy i větší pravděpodobnost sankcí za tyto ,prohřešky' (Quinney, 1970, cit. in Kivett, Warren, 2002). Oproti dívkám se život chlapců v DDÚ Archa řídí menším počtem institucionálních norem, tudíz jsou méně ohroženi prípadnými bodovými postihy a tresty. Distribuce sociální kontroly v DDÚ Archa je tedy prokazatelně genderově nerovná. $V$ praxi je legitimizována odkazem na jednoduchost a předvídatelnost bodového systému.

„[Bodový systém znamená] velkou jistotu, velkou možnost zpětný vazby, okamžitě, to dítě hned zjistí, rychlou orientaci, podporu, sebehodnoceni, jsem dobrej, dařilo se mi, jednoduchost, sladěnost těch dètí i dospělejch, vždycky se z toho dá udělat nějaká výjimka, dá se i tak jako teda vybočit v zájmu toho dítěte a ku prospěchu těch ostatních, to znamená, že nejsem limitovaný tím, že je to nějaký neživý systém, který by ty děcka nějak znevýhodňoval, naopak je to ohromná podpora v tom orientování se tady..." (zaměstnankyně DDú Archa)

Na základě dosud řečeného je možné tvrdit, že jakmile se dívka dostane do DDÚ, snaží se ji dospělí pracovníci/pracovnice vtěsnat do ,správné genderové škatulky', což se projevuje v podstatě na všech úrovních fungování instituce. Reakcí dívky na genderovou konformizaci ovšem může být vzdor a následné ohodnocení odmítavého chování dívky černými body. ${ }^{9}$ Důsledkem může být přisouzení určité nálepky, s nimiž se v rámci sociální pedagogiky běžně pracuje. Sochưrek (2001) by vzdorovité chování, negativismus a nerespektování norem pravděpodobně zařadil do kategorie tzv. disociálního chování.

Jak je patrné, (re)produkcí disociálního chování dětí si ústavní zařízení může zajištóvat legitimizaci vlastní existence a př́slibem nápravy takového chování posilovat svůj společenský význam (Foucault, 1980; 1999; 2000).

\subsection{Gender „mocenský“}

Co udržuje moc v jejím trvání, co ji činí akceptovanou, je skutečnost, že tato překračuje a produkuje věci, vyvolává potěšení, formuje vědění, produkuje diskurz. Musí být chápána jako produktivní sít, která prochází celým sociálním tělem, daleko spíše než jako negativní instance, jejiž funkcí je represe (tamtéž).

Fenomén moci můžeme ve vztahu k tématu výzkumu nezasvěcenou optikou chápat jako snahu agentů/agentek sociální kontroly dohližet nad dodržováním sociálních norem a jejich nedodržování z pozice svého vlivu sankcionovat. S vyšší mírou vhledu pak jako úsilí historicky se formující nápravné pedagogiky (a dnešní speciální pedagogiky) coby ztělesněného vědění (knowledge) zmocnit se diagnostických nálepek, a ty poté ve jménu vědy aplikovat na vybrané jedince. Moc diagnostických

\footnotetext{
${ }^{9}$ Poznatky korespondují s tezí Schaffner (2007), že „násilí proti dívkám vyvolává násilí u dívek“ (violence against girls provokes girls violence; cit. z názvu článku). V tomto případě jde o násilné dělání genderu, které může vést k agresivním projevům v chování dívek.
} 
nálepek je, zdá se, upevňována minimálně ve dvou směrech - diagnostické nálepky se stávají součástí identity jejich nositelů/nositelek tím, že jednotlivé druhy nenormality jsou distribuovány $v$ rámci diferencované sítě ústavních zařízení (ústavy sociální péče pro mládež, dětské psychiatrické léčebny, dětské domovy se školou, výchovné ústavy, dětské domovy, léčebně-výchovná oddělení aj.). Tento efekt je z druhé strany podpořen jejich poměrně „ochotnou“ absorpcí - vždyt' jde o proces, který má dítěti pomoci, "vyléčit ho“. (Skoro by se mohlo zdát, že se rodiči uleví, když se dozví, že dítě má oficiální diagnózu, než že bez zjevné př́činy zlobí.) A dost možná se ulevuje i dalším článkům (ohniskům) řetězce re/produkujícím moc (Foucault, 1980):

„Cílem zařízení (DDÚ Archa, pozn. aut.) je, aby se dotyčný dítě umistilo do toho správného zařízení, aby se vybral vhodný typ zařízení, kerý tomu určitýmu dítěti vyhovuje." (zaměstnankyně DDú Archa)

Jakkoli se zdá být logické vydělovat jednotlivé druhy nenormálního chování či smýšlení od sebe navzájem zaprvé proto, aby se nám vně těchto ústavů vyjevila normalita, a zadruhé proto, aby na jednotlivé typy nenormality bylo možné specializovaně odborně působit, má tato forma argumentace, kterou často užívají institucionalizované formy vědění (knowledge), jistou trhlinu. Při bližším zkoumání zjistíme, že na jeden typ ústavu nepřipadá jeden druh nenormality, nýbrž je jich více. Právě v okamžiku, kdy si uvědomíme, že je přesně dáno, jaké druhy nenormality je pod záštitou odbornosti speciálně-pedagogickým institucím umožněno navzájem mísit (např. děti s poruchami pozornosti, se syndromem $\mathrm{CAN}^{10}$ či s podprůměrným IQ /hodnoty 80-90/ v rámci dětských domovů) a jaké již tvoří diferencované kategorie (děti s IQ pod 80 do ústavu sociální péče pro mentálně postižené, děti dopouštějící se útěků z nápravných zařizení či děti projevující se jinak než heterosexuálně do výchovných ústavů, resp. dětských domovů se školou), ${ }^{11}$ zachytíme moc v jejím plném rozsahu: nejde jen o to konceptuálně odlišit a prostorově segregovat normální a nenormální, nýbrž i vědomě konfrontovat vybrané sociální odchylky mezi sebou (Foucault, 2000).

„....[Důvody k umistění do DDÚ Archa jsou] asi všechny, které si umí prèedstavit normální rodina, když žádá o nějakou terapeutickou intervenci... Takže na straně těch rodičů nějaká hyperprotektivní výchova, nedostačivá výchova zase, nějaká př̌sná výchova, tejráni, nezájem o děti, zneuživání, bezradnost, prostě i nějaký věci, které nemusejí být jako nějak známý. U těch dětí múžou být zase rưzný těžkosti, útěky z domova, vrácená pěstounská péče... nebo to jsou třeba vývojové krize, které to jsou jako takové vděčné k řešení tady u nás, protože tu krizi tady dokážeme nějak podchytit, nějak zvládnout a to dítě vrátit domů. ... A potom určitě nějaké školni problémy, výchovný problémy..., protože spousta těch dětí by tady nemusela být, kdyby ta záchytná sit' mohla fungovat líp, to znamená, že by škola nesignalizovala, my už si s ním nevíme rady, a tak jde do ústavu. " (zaměstnankyně DDú Archa)

V novodobé éře ústavů se tomuto mocenskému mechanismu říká „komunitně-terapeutický systém“ (Vnitřní řád DDÚ Archa), jenž je typický pro DDÚ jako přestupnou stanici pro téměř všechny institucionalizované děti, u kterých existuje předpoklad, že jsou schopny se vzdělávat $v$ běžném školském zařízení. ${ }^{12}$ Těžiště tohoto systému představuje myšlenka, že je žádoucí seskupovat nositele/nositelky různých diagnostických nálepek pod jednou střechou, nebot' to má pro všechny zúčastněné terapeutický (rozuměno léčebný) význam. Nenormalita by se tedy mohla zdát být

\footnotetext{
${ }^{10}$ Syndrom týraného, zanedbávaného a zneužívaného dítěte (Child Abuse and Neglect).

${ }^{11} \vee$ této souvislosti je nezbytné zmínit, že inteligenční kvocient, jakož i ,poruchy pozornosti‘ či ,poruchy chování jsou kulturními konstrukty, etablovanými v rámci speciálně-pedagogického vědění (knowledge), nikoliv biologické danosti, jak je s nimi někdy konceptuálně zacházeno (srov. Gould cit. in Snyder, Mitchell, 2006: 7273). Dislokační procesy dětí se tak odehrávají na podkladě těchto konstruktů a mohou pro ně být v konečném důsledku diskriminující, nebot' ne každé zařízení např. disponuje vzdělávacím zařízením s programem praktické či speciální školy. Spektrum disponibilních zařízení pro konkrétní dítě se tak zásadně limituje.

${ }^{12}$ Jak blíže specifikuje zákon č. 109/2002 Sb., do zařízení jsou umístovány i děti s mentálním, tělesným, smyslovým postižením či s kombinovaným postižením, pokud stupeň zdravotního postižení neodpovídá jejich umístění do ústavu sociální péče (§ 2, zákona č. 109/2002 Sb.).
} 
vyléčitelná ( $v$ této logice by právě diagnostický ústav byl institucí léčebnou - přinášející uzdravení nenormálním jedincům). Je-li ale výstupem z diagnostického pobytu závěrečná zpráva o dítěti, jež obsahuje bezpočet diagnostických nálepek, a následné dislokování dítěte do ústavu specializovanějšího, pak výsledkem není vyléčení nenormality, nýbrž jeho pravý opak: reprodukce nenormality, její oficiální stvrzení, posílení, posvěcení dalšími společenskými autoritami, což může být zdrojem následné stigmatizace, prípadně internalizace stigmatu (Goffman, 2003).

Účinky moci se zcela explicitně projevují v síle "diagnostické nálepky“, jejiž působení bylo podrobně rozpracováno v teorii etiketizace (Becker, 1963).

Děti, které do DDÚ Archa nastoupí, si mohou ponechat své civilní oblečení, pokud jej vlastní. Přesto se v oblasti oblékání objevuje zajímavý způsob etiketizace. Dítě, které se dopustí přestupku proti vnitřnímu rádu v podobě útěku ze zařízení, je po návratu (at již dobrovolném či vynuceném) oblečeno do jasně zeleného trika (to je nošeno vždy navrch nad prípadnými jinými vrstvami oblečení). Dítě jej nosí na všechny denní činnosti a nazýváno je „útěkářem“.

„....To zelený tričko jim neumožňuje, aby teda nosili navenek svoje věci a na tom mají to zelené tričko, tak je to prostě označení, ... mají to útěkáŕi, že jo, to znamená, že jako stojím za pozornost těm ostatním, protože moje spolehlivost je nějakým způsobem ohrožena. A zelený tričko není černý, takže zase si všichni prejeme, aby to ditě zase o tohle všechno prišlo, ale je to v podstatě informace i pro ty všechny dospělí, co tady pracujou, který se tady střídaji ve službách, kteří si to samozřejmě všechno prečtou o svých dětech, ale protože s těmi dětmi je v kontaktu i spousta jiných lidí. Já nevím, ty děti se tady pohybujou, já nevim, jdou si třeba do prádelny nebo nějak jinak a vidí někoho, že má zelený tričko, tak ví, že je to dítě, které potřebuje nějak pozornost a péči, takže je to na obě strany, je to nějaká sankce... Já si vzpomínám, když jsem byla v Densu, tak tam mají ty pozice označený taky jiným úborem..." (zaměstnankyně DDÚ Archa)

Nezanedbatelným znakem legitimizace vlastní moci je rovněž napojení nápravného systému na pedagogiku, respektive školský systém. Tím, že se v novodobé historii snaha o nápravu ,morálně zkažené' mládeže stala sférou zodpovědnosti resortu školství, se začala donucovací moc nápravného zařízení organizovat okolo institutu povinné školní docházky, která byla ještě o něco dříve ustanovena zákonem. Konsekvencí tohoto historického milníku je myšlenka, že k vynucení zákonné povinnosti systém speciálně-pedagogických institucí prakticky nevyhnutelně potřebujeme, což je další z efektů působící moci.

Soudobá snaha většiny zařízení náhradní výchovy diskurzivně se vymezovat vůči dřívějším označením, jakými jsou ,polepšovna' či ,pasták', je doprovázena snahou o diskurzivní splynutí se systémem pedagogických institucí. ${ }^{13}$ Zařízení dbají na to, aby se i jejich veřejný obraz odvozoval od jejich oficiálního přináležení pod resort školství (srov. Dvořák cit. in Senát, 2001). Nicméně pokud by v principu těchto ústavů šlo pouze o ,vynucení povinné školní docházky, nemusela by se zařízení nutně uchylovat $\mathrm{k}$ dalším disciplinačním technikám a praktikám, jež s povinnou školní docházkou ani vzdáleně nesouvisejí. Kolem institutu povinné školní docházky se tak nastoluje režim moci, jenž je založen na permanentním dohledu a kontrole nad běžně vykonávanými aktivitami. Snaha definovat zařízení jako ,školská' či ,pedagogická‘ se pak jeví jako pouhá diskurzivní manipulace, zástěrka status quo.

Michel Foucault (1980) permanentně zdůrazňuje pozitivní (produktivní) charakteristiky moderních aparátů moci a je přesvědčen, že jejich účinnost závisí na ustavení toho, co nazývá politikou či režimem pravdy (regime of truth; s. 237). V citovaném díle Power/Knowledge autor

\footnotetext{
${ }^{13}$ Příkladem je vznik termínu, dětský domov se školou' pro výchovné zařízení s přísnějším režimem, běžně označované jako ,polepšovna' či ,pasták'. Jak vyplývá ze samotného názvu, to, co činí tento typ zařízení prísnějším oproti dětskému domovu, je přítomnost školy v budově zařízení. Dítě se tak nachází pod kontrolou i v jinak, rizikových' prèechodech do školy a ze školy, kde by mohlo podlehnout celé řadě ,svodů’ z vnějšího prostředí.
} 
vyjasňuje, jak se vztah mezi věděním a mocí promítá v kulturně a historicky specifických režimech pravdy:

Pravda nestojí mimo moc, nýbrž je věcí tohoto světa: je produkována vlivem mnohonásobných forem omezení. Každá společnost má svůj režim pravdy, svou ,všeobecnou politiku' pravdy, tj. určité typy diskurzů, které akceptuje jako pravdivé; mechanismy a instance, které umožňují rozlišit pravdivá a nepravdivá tvrzení; prostředky sankcionace; uznávané techniky a procedury získávání pravdy; status těch, kteří jsou oprávněni říkat, co je a co není pravdivé (Foucault, 1980: 131).

Z uvedených tvrzení je možné vyvodit, že i DDÚ má svou specifickou politiku pravdy a svůj režim moci. Protiargument, že diagnostický ústav představuje zmenšený model či vzorek určitého druhu společnosti jako celku, a tudíz se $v$ něm uplatňuje stejný režim vědění/moci jako ve zbytku společnosti (a tudíz se nabízí otázka, proč si zasluhuje naši výzkumnou pozornost), ve světle uvedeného nemůže obstát. Diagnostický ústav sice částečně odráží i společenský mocenský systém, ale navíc disponuje vlastními normami, pravidly, kontrolními mechanismy a disciplinačními praktikami, které zesilují celospolečensky obíhající genderové předsudky a stereotypy a vyvolávají nepředvídatelné efekty. Produktivní povaha moci, která je společným jmenovatelem těchto praktik a mechanismů, dala vzniknout systému, jenž se $v$ rámci této studie dostal do centra zasloužené pozornosti.

\section{SHRNUTÍ VÝZKUMNÝCH VÝSLEDKŮ}

Terénní výzkum české instituce pro výkon ústavní a ochranné výchovy ukázal, že dětský diagnostický ústav pưsobí jako jedna z významných institucionálních sil, které udržují rozdíly mezi muži a ženami (chlapci a dívkami) a dávají jim status prirozenosti a správnosti.

Vzhledem $\mathrm{k}$ tomu, že instituce je současně důležitým mechanismem sociální kontroly, jsou výzkumně cenné identifikované normy, na jejichž zachování se spolu s dalšími agenty/agentkami sociální kontroly podílí. Jednou z těchto norem je povinná heterosexualita při současném zneviditelňování jiných forem sexuality s výjimkou homosexuální. Právě na základě strategie explicitního potlačování homosexuality je dosaženo posilování heteronormativního řádu. Homosexualita se stává prostředkem potvrzení dominantního postavení heterosexuality, takže mezi oběma formami sexuálního chování je ustaven vztah ve smyslu binárních opozic (Nagl-Docekal, 2007: 57-58).

Distribuce sociální kontroly je na všech úrovních systému genderově nerovná. Nejčastějšími důvody pro ústavní umist́ování dívek jsou statusové delikty (konkrétně tzv. „předčasně zahájený sexuální život“), které odrážejí spíše uplatňovaný "dvojí metr“ na výchovu chlapců a dívek v důsledku biologického esencialismu a genderových stereotypů. Dívky jsou v tomto smyslu pod daleko přísnějším dohledem pečujících osob než chlapci a jsou na ně uplatňovány mnohem přísnější mravní normy, což odráží principy genderově stereotypní výchovy. Vzhledem k vyššímu počtu genderovaných pravidel vztahujících se k chování dívek, jsou znevýhodněny statisticky vyšší pravděpodobností jejich porušení.

Dívky jsou v systému zařízení pro výkon ÚV a OV také zcela explicitně znevýhodněny vzhledem k nižšímu počtu disponibilních následných zařízení (a z tohoto důvodu nižší dostupnosti dané lokality pro rodinu), ale i s ohledem na omezenější nabídky studijních oborů. Stávající situace je v rozporu s ideou rovných př́ležitostí pro ženy a muže. 


\section{ZÁVĚR}

Cílem článku bylo objasnit, jak je genderován život v síti zařízení pro výkon ústavní a ochranné výchovy a v rámci konkrétního diagnostického ústavu v České republice. $V$ anonymizovaném DDÚ Archa proto byly formou terénního výzkumu zhuštěně interpretovány aspekty každodenního života umístěných dětí z genderové perspektivy.

Výzkum ukázal, že diagnostický ústav má svou specifickou politiku pravdy a svưj režim moci (Foucault, 1980). Disponuje vlastními normami, pravidly, kontrolními mechanismy a disciplinačními praktikami, které zesilují celospolečensky obíhající předsudky a stereotypy a vyvolávají nepředvídatelné efekty.

DDÚ Archa funguje v interakci moci/vědění, jak ji popisuje Foucault (tamtéž), nicméně tento vztah se ukázal být výrazně genderován. Genderové role a identity jsou re/konstruovány prostřednictvím ohnisek působící moci. Mezi její nositele náleží bodový systém hodnocení chování, interní předpisy týkající se zkrášlovacích procedur děvčat a chlapců, oblékání apod., uplatňující se rituály, ale i architektonické uspořádání budovy, kde se (genderová) resocializace odehrává.

Studovaný DDÚ Archa dále prokazatelně vykazuje vybrané charakteristiky totální instituce, jak ji popsal Goffman (1961). Všechny fáze denních (i týdenních) aktivit probíhají podle přesného harmonogramu (plánu), přičemž celkový průběh aktivit je na jedince uvalován shora systémem explicitních pravidel a autoritou. Tyto načasované aktivity dohromady vytváŕí jednotný plán v zájmu naplnění oficiálních cílů instituce (tamtéž, s. 5-6). Zařízení se sice na jedné straně jeví „otevřenějši“ navenek - oproti historickým ústavům poloviny 20. století vykazuje minimální formy zjevných represivních opatření (medikace, pohybová omezení, mříže aj.). Na straně druhé se výzkumem odkrývají skrytější a do jisté míry sofistikovanější mocenské mechanismy, které legitimizují existenci DDÚ i jeho režim pravdy.

Na reprodukci vztahu vědění/moc se v neposlední řadě podílejí přítomné diskurzy prakticky všech pomáhajících profesí, které poskytují generovaným procedurám potřebnou odbornost (komunitněterapeutický systém, poskytnutí hranic pro zdravý vývoj dítěte aj.).

Výzvou pro sociální pedagogiku budiž především kritické přehodnocení poslání a cílů instituce náhradní výchovy, která nereflektovaně zvyšuje sociální nerovnosti mezi umístěnými dívkami a chlapci, což je v prímém rozporu s deklarovaným oficiálním zájmem instituce i se zájmy sociální pedagogiky jako aplikované disciplíny.

\section{LITERATURA}

Barnard, A. (2000). History and Theory in Anthropology. Cambridge: Cambridge University Press.

Becker, H. S. (1963). Outsiders: Studies in the Sociology of Deviance. New York: Free Press.

Bobková, J. (2009). Kriminalita nezletilých dètí ve výkonu ústavní a ochranné výchovy z genderové perspektivy. Nepublikovaná magisterská diplomová práce. Praha: Fakulta humanitních studií Univerzity Karlovy.

Bourdieu, P. (2000). Nadvláda mužů. Praha: Karolinum.

Buchbinder, M., Longhofer, J., Barrett, T., Lawson, P., \& Floersch, J. (2006). Etnographic Approaches to Child Care Research: A Review of the Literature. Journal of Early Childhood Research, 1(1), 45-63.

Butler, J. (1990). Gender Trouble. Feminism and the Subversion of Identity. London: Routledge.

DDÚ Archa (2011). Inzerát [online]. Studované DDÚ [cit. 20. 5. 2011]. Dostupné z webových stránek DDÚ. 
DDÚ Plzeň. Kronika DDÚ Plzeň [online]. Plzeň: DDÚ Plzeň [cit. 26. 10. 2011]. Dostupné z: $<$ http://www.dduplzen.cz/historie.htm>.

Dvořák, J. (2001). Stenografický zápis z veřejného slyšení konaného dne 15. března 2001 v Senátu Parlamentu České republiky na téma Ústavní výchova dětí a mládeže v resortu Ministerstva školství, mládeže a tělovýchovy České republiky [online]. Praha: Senát [cit. 20. 5. 2011]. Dostupné z: <http://www.senat.cz>.

Edelsberger, L. (2000). Defektologický slovník. Praha: Nakladatelství H \& H.

Foucault, M. (1980). Power/Knowledge: Selected Interviews and Other Writings. New York: Pantheon Books.

Foucault, M. (1999). Dějiny sexuality I. Vưle k vědění. Praha: Herrmann a synové.

Foucault, M. (2000). Dohližet a trestat. Praha: Dauphin.

Foucault, M. (2002). Archeologie vědění. Praha: Herrmann \& synové.

Foucault, M. (2003). Myšlení vnějšku. Praha: Herrmann \& synové.

Foucault, M. (2010). Zrození kliniky. Červený Kostelec: Nakladatelství Pavel Mervart.

Geertz, C. (2000). Interpretace kultur. Praha: Sociologické nakladatelství.

Giddens, A. (1999). Sociologie. Praha: Argo.

Goethe, J. W. (2004). Smyslově-morální účinek barev. Hranice: Fabula.

Goffman, E. (1961). Asylums. Essays on the Social Situation of Mental Patients and Other Inmates. New York: Anchor Books.

Goffman, E. (1976). Gender Advertisements. Studies in the Anthropology of Visual Communication, $3(2), 69-154$.

Goffman, E. (2003). Stigma. Poznámky o způsobech zvládání narušené identity. Praha: Sociologické nakladatelství.

Gray, E. (2007). Are You Married, Sir? Heteronormativity in British Schools and its Impact upon Queer Staff and Pupils - a Generational Perspective. In K. Kolarova \& V. Sokolova (Eds.), Gender and Generation. UK: Lancaster University.

Hammersley, M., \& Atkinson, P. (1995). Etnography: Principles in Practice. London/New York: Routledge.

Hašková, H. (2000). K gender kontraktu v české společnosti 90. let. Gender, rovné príležitosti a výzkum, 1.

Havelková, H. (2004). První a druhá vlna feminismu: podobnosti a rozdíly. In L. Formánková \& K. Rytírová (Eds.), ABC feminismu. Brno: Nesehnutí.

Hoagland, S. (1999). Morálna revolúcia: Od antagonizmu k spolupráci. Aspekt, 1. 4-13.

Janebová, R. (2006). Gender aspekty v sociální práci s rizikovou mládeží. In Z. Truhlářová \& M. Smutek (Eds.). Riziková mládež v současné společnosti. Hradec Králové: Gaudeamus.

Karsten, H. (2006). Ženy - muži. Genderové role, jejich původ a vývoj. Praha: Portál

Katz, J. N. (2002). The Invention of Heterosexuality. In K. L. Peiss (Ed.). Major Problems in the History of American Sexuality. Documents and Essays. Boston: Houghton Mifflin.

Kaufmann-Huber, G. (1998). Děti potrebuji rituály. Praha: Portál.

Kimmel, M. S. (2000). The Gendered Society. New York: Oxford University Press. 
Douglas K. D., Carol, A., \& Warren, B. (2002). Social Control in a Group Home for Delinquent Boys. Journal of Contemporary Ethnography, 1. 3-32.

Křižková, A., \& Pavlica, K. (2004). Management genderových vztahů. Postavení žen a mužů $v$ organizaci. Praha: Management Press.

Kuruc, A., \& Smitková. H. (2007). Rod/gender ako sociálna kategória v psychoterapii a poradenstve. Československá psychologie, 1. 269-278.

Makaloušová, I. (2008). Barvy a jejich působení na psychiku dítěte v mateřské škole. Bakalářská práce. České Budějovice: Jihočeská univerzita.

Matoušek, O. a kol. (2001). Základy sociální práce. Praha: Portál.

Monatová, L. (1998). Pojetí speciální pedagogiky z vývojového hlediska. Brno: Paido.

Možný, I. (2006). Rodina a společnost. Praha: SLON.

Musil, L. (2004). Ráda bych vám pomohla, ale.... Dilemata práce s klienty v organizacích. Brno: Marek Zeman.

Nagl-Docekal, H. (2007). Feministická filozofie. Praha: Sociologické nakladatelství.

Nedbálková, K. (2006). Spoutaná rozkoš. Sociální (re)produkce genderu a sexuality v ženské věznici. Praha: SLON.

Pavlík, P. (2002). O znásilnění: Kontra hegemonní diskurs. Gender, rovné přiležitosti a výzkum, 3(1). 3-6.

Pratt, A. (1981). Archetypal Patterns in Women's Fiction. Bloomington: Indiana University Press.

Reinharz, S. (1992). Feminist Methods in Social Research. New York: Oxford University Press.

Renzetti, M., \& Curran, D. J. (2005). Ženy, muži a společnost. Praha: Karolinum.

Scott, J. (1986). Gender: A Useful Category of Historical Analysis. The American Historical Review, 1(5). 1053-1075.

Sheafor, B. W., \& Horejsi, Ch. R. (2000). Techniques and Guidelines for Social Work Practice. Boston: Allyn and Bacon.

Schaffner, L. (2007). Violence Against Girls Provokes Girls' Violence: From Private Injury to Public Harm. Violence against Women, 1(13). 1228-1248.

Smetáčková, I. (Ed.). (2007). Př́ručka pro genderově citlivé výchovné poradenství. Praha: Otevřená společnost, o. p. s.

Smetáčková, I., Jára, M., Miškolci, J., \& Babanová, A. (2008). Manuál pro vyučující k učebnici Na cestě $k$ vlastní rodině: kapitoly z rodinné výchovy. Praha: Otevřená společnost, o. p. s.

Snyder, S. L., \& Mitchell, D. T. (2006). Cultural Locations of Disability. Chicago: The University of Chicago Press.

Sochůrek, J. (2001). Vybrané kapitoly ze sociální patologie I. díl. Liberec: Technická univerzita.

Štech, S. (2006). Násilí ve škole, násilí proti škole, násilí školy. In S. Kariková (ed.). Násilie na školách. Banská Bystrica: PedF UMB.

Švaříček, R., \& Šed'ová, K. (2007). Kvalitativní výzkum v pedagogických vědách. Praha: Portál.

Tew, J. (2006). Understanding Power and Powerlessness: Towards a Framework for Emancipatory Practice in Social Work. Journal of Social Work, 1(1). 33-51. 
Thorne, B. (1978). Gender... How Is It Best Conceptualized? Unpublished Paper Presented at Annual Meetings of the American Sociological Association. San Francisco.

Uhde, Z. (2004). Feministické teorie: spor o pojetí genderu. Gender, rovné príležitosti a výzkum, 1(4). $1-4$.

Úlehla, I. (2005). Umění pomáhat. Praha: Sociologické nakladatelství.

Valdrová, J., Knotková-Čapková, B., \& Paclíková, P. (2010). Kultura genderově vyváženého vyjadřování [online]. Praha: MŠMT [cit. 2. 1. 2013]. Dostupné z: <http://www.zabanaprameni.cz/aktuality/436/kultura-genderove-nevyvazeneho-vyjadrovaniv-praxi-a-prirucka-ktera-ma-zpozdeni>.

Dülmen, V. R. (2002). Historická antropologie. Praha: Dokořán.

Vnitřní řád DDÚ Archa, platný od 1. 9. 2007.

West, C., \& Zimmerman, D. H. (1987). Doing Gender. Gender \& Society, 1(2). 125-151.

\title{
Zákony a vyhlášky
}

Vyhláška č. 505/2006 Sb., prováděcí předpis k zákonu č. 108/2006 Sb., o sociálních službách, v platném znění.

Zákon č. 109/2002 Sb., o výkonu ústavní výchovy nebo ochranné výchovy ve školních zařízeních a o preventivně výchovné péči ve školských zařízeních a o změně dalších zákonů.

\section{Autor}

Mgr. Jana Benešová, Karlova univerzita v Praze, Fakulta humanitních studií, U Kř́iže 10, 15800 Praha 5, e-mail: janabenesu@seznam.cz

\section{How gender is born in a diagnostic child-care facility}

\begin{abstract}
The article is a summary of the main findings concerning (re)construction of the gender identities of children placed in a contemporary diagnostic child-care facility in the Czech Republic. The research setting has the fictitious name DDÚ Archa. The author of the arcticle is summarizing the interim results from her Ph.D. dissertation project. The goal is to catch processes which have been neglected so far by the Czech professional community, and which may become potential disciplinary tools in the hands of professionals in a wide range of helping professions, including social and special pedagogy.
\end{abstract}

Keywords: Diagnostic child-care facility, gender, power, thick descriptions 